\title{
EZH2 Methyltransferase Activity Controls Pten Expression and mTOR Signaling during Fear Memory Reconsolidation
}

\author{
Timothy J. Jarome, $\mathbb{C}^{-G a b r i e l l a ~ A . ~ P e r e z, ~} @$ Rebecca M. Hauser, Katrina M. Hatch, and ${ }^{\circ}$ Farah D. Lubin \\ Department of Neurobiology, University of Alabama at Birmingham, Birmingham, Alabama 35294
}

\begin{abstract}
Memory retrieval induces a transient period of increased transcriptional and translational regulation in neurons called reconsolidation, which is regulated by the protein kinase B (AKT)-mammalian target of rapamycin (mTOR) pathway. However, it is currently unknown how activation of the AKT-mTOR pathway is regulated during the reconsolidation process. Here, we found that in male rats retrieval of a contextual fear memory transiently increased Enhancer of Zeste Homolog 2 (EZH2) levels along with increased histone H3 lysine 27 trimethylation (H3K27me3) levels, which correlated with decreased levels of phosphatase and tensin homolog (PTEN), a potent inhibitor of AKT-mTOR-dependent signaling in the hippocampus. Further experiments found increased H3K27me3 levels and DNA methylation across the Pten promoter and coding regions, indicating transcriptional silencing of the Pten gene. Pten H3K27me3 levels did not change following training or after the retrieval of a remote (old) fear memory, suggesting that this mechanism of Pten repression was specific to the reconsolidation of a new memory. In vivo siRNA-mediated knockdown of Ezh2 in the hippocampus abolished retrieval-induced increases in H3K27me3 and prevented decreases in PTEN levels. Ezh2 knockdown attenuated increases in the phosphorylation of AKT and mTOR following retrieval, which could be restored by simultaneously reducing Pten, suggesting that H3K27me3 regulates AKTmTOR phosphorylation via repression of Pten. Consistent with these results, knockdown of Ezh2 in area CA1 before retrieval impaired memory on later tests. Collectively, these results suggest that EZH2-mediated H3K27me3 plays a critical role in the repression of Pten transcription necessary for AKT-mTOR activation and memory reconsolidation following retrieval.
\end{abstract}

Key words: chromatin; epigenetics; gene expression; hippocampus; histone methylation; retrieval

Significance Statement

Understanding how critical translation pathways, like mTOR-mediated protein synthesis, are regulated during the memory storage process is necessary for improving memory impairments. This study tests whether mTOR activation is coupled to epigenetic mechanisms in the hippocampus following the retrieval of a contextual fear memory. Specifically, this study evaluates the role of epigenetic modifications in the form of histone methylation in downstream mTOR translational control during learningdependent synaptic plasticity in neurons. Considering the broad implications of transcriptional and translational mechanisms in synaptic plasticity, psychiatric, and neurological and neurodegenerative disorders, these data are of interest to the neuroscience community due to the robust and specific regulation of mTOR signaling we found to be dependent on repressive histone methylation.

\section{Introduction}

Increased protein synthesis is critical for learning-dependent synaptic plasticity in the brain. Supporting this, a number of studies

Received Feb. 19, 2018; revised June 20, 2018; accepted July 7, 2018.

Author contributions: T.J.J. and F.D.L. designed research; T.J.J., G.A.P., R.M.H., K.M.H., and F.D.L. performed research; F.D.L. contributed unpublished reagents/analytic tools; T.J.J., G.A.P., R.M.H., K.M.H., and F.D.L. analyzed data; T.J.J. and F.D.L. wrote the paper.

This work was supported in part by National Institutes of Health (NIH) Grants MH-097909 and NS-090250 to F.D.L., and by the Evelyn F. McKnight Brain Institute at the University of Alabama at Birmingham (UAB). T.J.J. is supported by a postdoctoral fellowship from the American Federation for Aging Research (PD16051). G.A.P. is supported by the UAB Prep Scholar Program. R.M.H. is supported by NIH Institutional Training Grant NS095775.

The authors declare no competing financial interests.

Correspondence should be addressed to Dr. Farah D. Lubin, Department of Neurobiology, Shelby Building, University of Alabama at Birmingham, 1825 University Boulevard, Birmingham, AL 35294. E-mail: flubin@uab.edu. have shown a requirement for de novo protein synthesis in neurons for the formation of long-term memories following learning (Schafe and LeDoux, 2000), a process termed "consolidation" (McGaugh, 2000). Additionally, upon retrieval, once consolidated memories become labile and require new protein synthesis to restabilize, a process referred to as "reconsolidation" (Nader et al., 2000). This reconsolidation process allows a transient period in which previously stored memories can be modified (Monfils et al., 2009; Gräff et al., 2014; Jarome et al., 2015a; Kwapis et al., 2017), which may have significant therapeutic potential for the 
treatment of maladaptive memories associated with a number of anxiety disorders. However, the cellular mechanisms of memory reconsolidation remain poorly understood, and how protein synthesis is regulated during activity- and learning-dependent synaptic plasticity remains equivocal.

One of the main translational control pathways involved in the reconsolidation process is the mammalian target of rapamycin complex 1 (mTORC1), which has been broadly implicated in learning-dependent synaptic plasticity in neurons (Parsons et al., 2006; Gafford et al., 2011; Jobim et al., 2012; Mac Callum et al., 2014). Phosphorylation of mTOR activates a number of downstream effectors involved in translation initiation and elongation, giving mTORC1 dynamic control over protein synthesis. However, to date, it is unknown how mTOR1 signaling is regulated during the reconsolidation process.

The mTORC1 is part of the phosphatidylinositol-4,5-biphosphate 3-kinase (PI3K)-protein kinase B (AKT)-mTOR (PI3K-AKTmTOR) pathway. In this pathway, PI3K phosphorylates phosphatidylinositol(3,4,5)-trisphosphate (PIP3), which regulates the phosphorylation of AKT through PDPK1. Once phosphorylated, AKT phosphorylates mTORC1 and leads to the activation of 4EBP1 [eukaryotic translational initiation factor 4E binding protein) and P70S6 kinase (P70S6K; Hoeffer and Klann, 2010). The $\mathrm{PI} 3 \mathrm{~K}-\mathrm{AKT}-\mathrm{mTOR}$ pathway is tightly regulated by the phosphatase and tensin homolog (PTEN), which dephosphorylates PIP3 leading to inactivation of AKT and mTORC1. Consequently, the dysregulation of PTEN levels can have dramatic effects on mTORC1-mediated protein synthesis and is associated with a number of different disease states. Interestingly, while some studies have suggested a role for PTEN in memory formation and storage (Sperow et al., 2012; Lugo et al., 2013; Mucic et al., 2015; Liu et al., 2016), it is unknown whether PTEN regulation is critical for mTORC1 activation following memory retrieval.

In cancer cells, Pten can be epigenetically regulated by the transcriptionally repressive mark $\mathrm{H} 3$ lysine 27 trimethylation (H3K27me3) which is catalyzed by the Enhancer of Zeste Homolog 2 (EZH2), the functional enzymatic component of PRC2 (polycomb repressive complex 2; Steelman et al., 2011; Song et al., 2012). Surprisingly, though epigenetic mechanisms have been widely implicated in memory storage processes in the brain (for review, see, Day and Sweatt, 2010; Jarome and Lubin, 2014; Kwapis and Wood, 2014) and some studies using whole epigenome and transcriptome analyses have begun to identify some of the downstream signaling pathways that are regulated by these chromatin modifications following learning (Halder et al., 2016), much remains unknown about the gene targets of epigenetic modifications following memory retrieval. Additionally, very little is known in general about the role of $\mathrm{H} 3 \mathrm{~K} 27 \mathrm{me} 3$ in memory storage processes in neurons (Zhang et al., 2014), and it is currently unknown whether H3K27me3-mediated repression of Pten is critical for mTORC1 activation during the memory reconsolidation process. In the present study, we found that $\mathrm{H} 3 \mathrm{~K} 27 \mathrm{me} 3$ regulated Pten repression necessary for mTOR phosphorylation during memory reconsolidation. As a result, we have identified a novel epigenetic pathway critical for the regulation of translational control mechanisms during memory reconsolidation.

\section{Materials and Methods}

\section{Subjects}

A total of 174 male Sprague Dawley rats (Harlan) weighing 250-300 g at the time of arrival were used for these experiments. Rats were single housed in plastic cages, had free access to water and rat chow, and were maintained on a $12 \mathrm{~h}$ light/dark cycle. All procedures were approved by the University of Alabama at Birmingham Institutional Animal Care and Use Committee and performed in accordance with the National Institutes of Health ethical guidelines.

\section{Surgery and siRNA infusions}

Rats were injected with Accell siRNAs (Dharmacon) as described previously (Jarome et al., 2015b; Webb et al., 2017). Fresh Accell Ezh2 (catalog \#E-094880-00-0005), Pten (catalog \#E-080104-00-0005), and nontargeting control (catalog \#D-001910-10-05) siRNA stocks $(100 \mu \mathrm{M})$ (Dharmacon) were resuspended in Accell siRNA resuspension buffer to a concentration of $\sim 4.5 \mu \mathrm{M}$ on the day of surgery. A nontargeting green fluorescent Accell siRNA (catalog \#D-001950-01, Dharmacon) was used to confirm targeting of the CA1 region.

\section{Behavioral procedures}

Rats were handled for $3 \mathrm{~d}$ followed by $3 \mathrm{~d}$ of acclimation to the transport procedure before the start of behavioral training. Rats were then trained to a standard contextual fear-conditioning paradigm in which three shock presentations $(0.6 \mathrm{~mA}, 2 \mathrm{~s}, 120 \mathrm{~s}$ Intertrial interval) were given over a $7 \mathrm{~min}$ period in a novel context (Med Associates). Following the completion of training, rats were returned to their homecages. To reactivate the memory, rats were placed back into the training context for $90 \mathrm{~s}$ in the absence of shock; no retrieval rats underwent the same training protocol but were not re-exposed to the training context on the retrieval day. Testing occurred the following day and consisted of a 5 min exposure to the training context. All behavior was recorded and scored live by Med Associates software (Freeze Scan).

\section{Specific experimental procedures}

Experiments 1-4. Rats were trained to contextual fear conditioning and the following day were re-exposed to the training context to reactivate the memory. In Experiment 1, the CA1 region of the dorsal hippocampus was then collected for protein analysis $1 \mathrm{~h}$ later (React; $n=6$ ). Separate rats were trained on Day 1, and the dorsal CA1 region was collected on Day 2 at times equivalent to those of the reactivation group, which served as the no reactivation (No React) control $(n=5)$. In Experiment 2, separate groups of rats were run through the same procedure above except that the dorsal CA1 region was collected for protein analysis $24 \mathrm{~h}$ after retrieval $(n=10)$ or at an equivalent time on Day $3(n=8)$. In Experiments 3 and 4, the same procedure was used as in Experiment 1 except that the collected tissue was used for chromatin immunoprecipitation (ChIP; Experiment 3) or methylated DNA immunoprecipitation (meDIP; Experiment 4) analysis. Experiment 3 group sizes were No react $n=6$, React $n=6$. Experiment 4 group sizes were No React $n=6$, React $n=8$.

Experiments 5 and 6. In Experiment 5, rats were trained to contextual fear conditioning, and the dorsal CA1 region was collected $1 \mathrm{~h}$ later for protein analysis (Trained; $n=5)$ and compared with naive rats $(n=4)$. Experiment 6 was identical except that tissue was collected for ChIP analysis with group sizes for Naive $n=4$ and Trained $n=5$.

Experiments 7 and 8. In Experiment 7, rats were stereotaxically injected with Accell siRNA targeting Ezh2 $(n=7)$ or a nontargeting control $(n=$ 8 ), and the dorsal CA1 region was collected $5 \mathrm{~d}$ later for RNA analysis. In Experiment 8, rats were stereotaxically injected with Accell siRNA targeting Ezh2 $(n=6)$ or a nontargeting control $(n=5)$ and were trained to contextual fear conditioning $5 \mathrm{~d}$ later. Twenty-four hours after training, rats were tested for retention to the context cue.

Experiments 9 and 10. In Experiment 9, rats were trained to contextual fear conditioning and re-exposed to the training context $1 \mathrm{~d}$ (Recent; $n=$ 6) or $30 \mathrm{~d}$ (Remote; $n=6$ ) later to reactivate the memory. One hour after retrieval, the dorsal CA1 region and the anterior cingulate cortex were collected for protein analysis. Control (No React; $n=6$ ) rats were trained and tissue collected on Day 2 or Day 31 and pooled to form a single control group. Experiment 10 included only the No React $(n=4)$ and Remote $(n=4)$ groups, and tissue was used for ChIP analysis.

Experiment 11. Rats were trained to contextual fear conditioning and the following day were stereotaxically injected with Accell siRNA targeting Ezh2 (Ezh2-siRNA React; $n=6$ ) or a nontargeting control (ScrsiRNA React; $n=5$ ). Five days later, rats were re-exposed to the training context to reactivate the memory and dorsal CAl tissue was collected $1 \mathrm{~h}$ 
later for protein analysis. A separate group of rats was trained on Day 1 and injected with control siRNA on Day 2, and dorsal CA1 was collected on Day 7; these rats served as the Scr-siRNA No React control group $(n=5)$.

Experiment 12. This is identical to Experiment 11 except that rats received either a nontargeting siRNA or a combination of Ezh2 and Pten siRNAs. One hemisphere was collected for RNA analysis and the other for protein analysis. For RNA analysis of one hemisphere, we were able to collect quantifiable RNA from 15 of 18 samples, resulting in the following group sizes: Scr-siRNA No React, $n=6$; Scr-siRNA React, $n=5$; and Ezh2 + Pten-siRNA React, $n=4$. For the protein analysis of the other hemisphere, we were able to collect a protein and histone fraction from all samples, resulting in six rats per group.

Experiment 13. Rats were trained to contextual fear conditioning and the following day were stereotaxically injected with Accell siRNA targeting Ezh2 $(n=8)$ or a nontargeting control (Scr-siRNA; $n=7)$. Five days later, rats were re-exposed to the training context to reactivate the memory and were tested for retention to the contextual cue $24 \mathrm{~h}$ later.

\section{Tissue collection and protein extraction}

Rats were killed with rapid decapitation, and the brain was flash frozen on dry ice. Coronal sections containing the medial prefrontal cortex or dorsal hippocampus and retrosplenial cortex (RSC) were dissected with the aid of a rat brain matrix. Area CA1, anterior cingulate cortex (ACC), and anterior RSC were homogenized in buffer $(50 \mathrm{~mm}$ Tris, $50 \mathrm{~mm} \mathrm{KCl}$, $250 \mathrm{~mm}$ sucrose) using a Teflon homogenizer. Protein and histone extracts were collected as described previously (Maity et al., 2016). Briefly, samples were homogenized in sucrose buffer $(320 \mathrm{~mm})$ with protease and phosphatase inhibitors. Homogenized samples were centrifuged at $7700 \times g$ for $1 \mathrm{~min}$, and the supernatant was collected. This supernatant was used for analysis of EZH2, PTEN, AKT, and mTOR levels. The resulting pellet was resuspended in $0.4 \mathrm{~N}$ sulfuric acid and incubated for 30 $\mathrm{min}$ on ice, followed by centrifuging at maximum speed for $10 \mathrm{~min}$. The supernatant was collected, and trichloroacetic acid with $4 \mathrm{mg} / \mathrm{ml}$ deoxycholic acid was added. Samples were incubated for $30 \mathrm{~min}$ on ice and centrifuged, and histones were collected by acetone drying. All protein samples were normalized using the Bio-Rad Bradford protein assay.

\section{Western blotting}

Normalized samples (3 $\mu \mathrm{g}$ for histones, 15-20 $\mu \mathrm{g}$ for whole cell) were loaded on $7 \%$ or $20 \%$ SDS-PAGE gels and transferred onto an Immobilon-FL membrane using a turbo transfer system (Bio-Rad). Membranes were blocked in LI-COR blocking buffer and probed with primary antibody overnight at $4^{\circ} \mathrm{C}$. Secondary goat anti-rabbit $700 \mathrm{CW}$ antibody (1:20,000; LI-COR) was used for the detection of proteins using the LI-COR Odyssey system, as described previously (Webb et al., 2017). Protein quantification was performed using GeneTools Software (Syngene). Mean pixel density was calculated for each sample, normalized to H3 (H3K27me3), actin (EZH2, PTEN), AKT ( phospho-AKT), or mTOR ( phospho-mTOR), and taken as a percentage of the control group.

\section{Antibodies}

Antibodies included the following: trimethylated H3 lysine 27 (1:1000 for Western blots, $5 \mu \mathrm{g}$ for ChIP; catalog \#07-449, EMD Millipore; RRID: AB_310624); H3 (1:1000; catalog \#ab1791, Abcam; RRID:AB_302613); EZH2 (1:1000; catalog \#ab3748, Abcam; RRID:AB_304045); phosphorylated AKT-Thr308 (1:1000; catalog \#2965, Cell Signaling Technology; RRID:AB_2255933); AKT (1:1000; catalog \#4691, Cell Signaling Technology; RRID:AB_915783); phosphorylated mTOR-Ser2448 (1:500 to 1:1000; catalog \#5536, Cell Signaling Technology; RRID:AB_10691552); mTOR (1:1000; catalog \#2983, Cell Signaling Technology; RRID: AB_2105622); PTEN (1:1000; catalog \#9559, Cell Signaling Technology; RRID:AB_390810); phosphorylated P70S6 kinase (1:1000; catalog \#9205, Cell Signaling Technology; RRID:AB_330944); P70S6 kinase (1: 1000; catalog \#2708, Cell Signaling Technology; RRID:AB_390722); and actin (1:1000; catalog \#4967, Cell Signaling Technology; RRID:AB_330288).

\section{ELISA}

Phosphorylated mTOR levels were determined using the Pathscan Sandwich ELISA Kit (catalog \#7976C, Cell Signaling Technology) according to the manufacturer instructions. A total of $20 \mu \mathrm{g}$ of homogenized CA1 tissue was used for each reaction. Results are an average of three runs and are presented as a percentage of the control group.

\section{RNA extraction and quantitative real-time PCR}

RNA was extracted from CA1 lysates using the Qiagen Allprep Kit and converted to CDNA, and real-time PCR amplifications were performed on the Bio-Rad CFX-96 Real Time System as described previously (GuptaAgarwal et al., 2014). All genes were ran in duplicate and compared with GAPDH. Cycle threshold $(\mathrm{Ct})$ values were analyzed using the comparative $\mathrm{Ct}$ method to calculate differences in gene expression between samples. Primers included the following: Ezh2 (forward-TCTCACCAGCTGC AAAGTGT, reverse-AGAGGAGTTGTGTTTTCCCACT); Pten (forwardCCAGTCAGAGGCGCTATGTA, reverse-TCCGCCACTGAACATTGG $\mathrm{AA}$ ); and GAPDH (forward-ACCTTTGATGCTGGGGCTGGC, reverseGGGCTGAGTTGGGATGGGGACT).

\section{ChIP}

ChIP assays were performed as described previously (Webb et al., 2017). Briefly, CA1 tissue was fixed in PBS with $1 \%$ formaldehyde for $10 \mathrm{~min}$ at $37^{\circ} \mathrm{C}$ and washed extensively in PBS. Samples were homogenized in hypotonic buffer ( $10 \mathrm{~mm} \mathrm{KCl,} 20 \mathrm{~mm} \mathrm{HEPES}, 1 \mathrm{~mm}, \mathrm{MgCl}, 1 \mathrm{~mm}$ DTT) with protease inhibitors and centrifuged at $1350 \times g$ for $10 \mathrm{~min}$ at $4^{\circ} \mathrm{C}$ to pellet nuclei. Pellets were resuspended in ChIP sonication buffer [ $1 \times$ TrisEDTA (TE) buffer with $1 \%$ SDS] with protease inhibitors and chromatin sheared to $300 \mathrm{bp}$ using 25 cycles on a Bioruptor at high power. Lysates were centrifuged at $20,000 \times \mathrm{g}$ for $10 \mathrm{~min}$ at $4^{\circ} \mathrm{C}$ to pellet debris and supernatant collected and DNA content measured using a nanodrop. Normalized amounts of DNA were diluted in TE buffer and $2 \times$ RIPA buffer ( $2 \times$ PBS, $1 \%$ sodium deoxylcholate, $2 \%$ NP-40, $0.2 \%$ SDS) with $2 \times$ proteasome inhibitors. Samples were added to Magna ChIP Protein A/G magnetic beads (EMD Millipore). Immunoprecipitations were performed at $4^{\circ} \mathrm{C}$ overnight with primary antibody (anti-H3K27me3) or no antibody (control). Immune complexes were collected and washed with low-salt buffer, high-salt buffer, $\mathrm{LiCl}$ immune complex buffer, and twice with TE buffer. Immune complexes were extracted in TE containing 1\% SDS and sodium bicarbonate, and protein-DNA cross-links were reverted by heating at $65^{\circ} \mathrm{C}$ overnight. After proteinase $\mathrm{K}$ digestion (100 $\mu \mathrm{g} ; 2 \mathrm{~h}$ at $37^{\circ} \mathrm{C}$ ), DNA was extracted by phenol/chloroform/isoamyl alcohol and then ethanol precipitated. Immunoprecipitated DNA samples were subjected to quantitative real-time PCR (qRT-PCR) using primers specific to the rat Pten promoter or coding region. The cumulative fluorescence for each amplicon was taken as a percentage of the input fraction, and enrichment over background (no antibody control) was calculated and taken as a fold change of the control group. We confirmed that the antibody produced Ct values that were significantly lower (sooner) than the no-antibody controls, indicating enrichment of the H3K27me3 mark. DNA primers were as follows: Pten promoter (forward-CTCTGGCT GCTGAGGAGAAG, reverse-CTGATGCCCCTCGCTCTG; product = 114 bp); and coding region (forward-ACCATAACCCACCACAGCTAGA, reverse-GCTGCAACATGATTGTCGTCT; product $=88 \mathrm{bp}$ ).

\section{meDIP}

Dissected CA1 samples were homogenized in TE buffer with 1\% SDS and $100 \mu \mathrm{g}$ of proteinase $\mathrm{K}$, incubated for $2 \mathrm{~h}$ at $55^{\circ} \mathrm{C}$, and DNA was extracted by phenol/chloroform/isoamyl alcohol and then ethanol precipitated. Normalized amounts of genomic DNA $(4 \mu \mathrm{g})$ were sheared to $\sim 300 \mathrm{bp}$, denatured at $95^{\circ} \mathrm{C}$ for $15 \mathrm{~min}$, diluted with IP buffer ( $16 \mathrm{~mm}$ Tris, $1.2 \mathrm{~mm}$ EDTA, $167 \mathrm{~mm} \mathrm{NaCl}, 1 \%$ SDS, 1\% Triton), mixed with MagnaChip magnetic protein $\mathrm{A} / \mathrm{G}$ beads, and immunoprecipitations were performed at $4^{\circ} \mathrm{C}$ overnight with primary antibody against 5 -methylcytosine $(5-\mathrm{mc}$; EpiGentek). Immune complexes were extensively washed and eluted, and DNA was extracted by phenol/chloroform/isoamyl alcohol and ethanol precipitation. Immunoprecipitated DNA samples were subjected to qRT-PCR using primers specific to the rat Pten promoter. The cumulative fluorescence for each amplicon was taken as a percentage of the input fraction and taken as a fold change of the control group. A fold change over background could not be calculated since we did not observe amplification in precipitated DNA from no-antibody control conditions. 
Statistical analyses

All data are presented as the mean and SE. Experiments with two groups were analyzed using independent-samples $t$ tests; those with three groups were analyzed with ANOVA followed by Fisher PLSD post hoc or $t$ tests where appropriate, unless otherwise indicated. Statistical outliers were defined as those that were $\geq 2$ SDs from the mean. For Western blots, outliers were removed from the final analysis on a case-by-case basis (e.g., based on individual antibodies) rather than being excluded from an entire dataset for meeting outlier criteria on one individual, independent analysis. For behavioral experiments, if an animal was an outlier during either training or testing, they were removed from both analyses since the two measures are not independent. The number of outliers and the analysis they were identified on are as follows: Experiment $1=1(\mathrm{EZH} 2$, PTEN); Experiment $2=1$ (EZH2, H3K27me3); Experiment $8=1$ (removed from training and test); Experiment $9=1$ (CA1-H3K27me3); Experiment $11=1$ (AKT, P70); and Experiment $12=1$ (H3K27me3, AKT, mTOR). During histone collection, one sample was lost in Experiment 1 and Experiment 9 (CA1) due to a centrifuge malfunction.

\section{Results}

\section{H3K27me3 levels increase at the Pten gene in the} hippocampus following retrieval

We first examined whether memory retrieval triggered changes in the repressive $\mathrm{H} 3 \mathrm{~K} 27$ me 3 mark in the hippocampus. Rats were trained to contextual fear conditioning and $24 \mathrm{~h}$ later were reexposed to the training context (Fig. 1a). Area CA1 of the dorsal hippocampus was then collected 1 or $24 \mathrm{~h}$ later, time points within and outside the reconsolidation window, respectively (Nader et al., 2000). We found that retrieval of the context fear memory increased EZH2 levels in area CA1 $1 \mathrm{~h}$ after retrieval $\left(t_{(8)}=\right.$ $3.518, p=0.0079)$, which returned to baseline by $24 \mathrm{~h}\left(t_{(15)}=\right.$ $1.095, p=0.2909$; Fig. $1 b$ ). Consistent with this, in bulk histone extracts from area CA1, we found increases in $\mathrm{H} 3 \mathrm{~K} 27 \mathrm{me} 3$ levels $1 \mathrm{~h}$ after retrieval $\left(t_{(7)}=2.404, p=0.0472\right.$; Fig. $\left.1 c\right)$. Surprisingly, $\mathrm{H} 3 \mathrm{~K} 27 \mathrm{me} 3$ levels were decreased $24 \mathrm{~h}$ after retrieval $\left(t_{(15)}=\right.$ $3.019, p=0.0086$ ), suggesting continued regulation of this histone methylation mark well beyond completion of the reconsolidation process (Gupta-Agarwal et al., 2012, 2014). Collectively, these results suggest that EZH2 methyltransferase and H3K27me3 methylation are upregulated during the reconsolidation process.

Pten is a known target of H3K27me3 in some cell types, so we next tested whether H3K27me3 was targeting Pten during the reconsolidation process. We observed a reduction in PTEN levels in CA1 protein lysates following memory retrieval $\left(t_{(8)}=2.173\right.$, $p=0.0308$; Fig. $1 d)$, which returned to baseline by $24 \mathrm{~h}\left(t_{(16)}=\right.$ $0.3359, p=0.7413)$, suggesting that the Pten gene could be associated with increased $\mathrm{H} 3 \mathrm{~K} 27 \mathrm{me} 3$. To further investigate this possibility, we performed ChIP assays on CA1 tissue collected $1 \mathrm{~h}$ after retrieval and examined H3K27me3 occupancy at the Pten promoter and coding regions (Fig. 1e). Remarkably, we found increased $\mathrm{H} 3 \mathrm{~K} 27 \mathrm{me} 3$ levels at the Pten coding region $\left(t_{(10)}=\right.$ 2.772, $p=0.0197$; Fig. $1 f$ ); however, H3K27me3 levels dramatically decreased within the Pten promoter region $\left(t_{(10)}=3.285\right.$, $p=0.0082$ ). While these results do support repression of Pten following retrieval, the loss of $\mathrm{H} 3 \mathrm{~K} 27 \mathrm{me} 3$ in the promoter region was unexpected. One possible explanation for the decreased $\mathrm{H} 3 \mathrm{~K} 27 \mathrm{me} 3$ within the promoter region could be the presence of DNA methylation, as a strong inverse relationship exists between H3K27me3 and DNA methylation (Lindroth et al., 2008; Brinkman et al., 2012; Statham et al., 2012; Reddington et al., 2013). Importantly, in mammals H3K27me3 levels are often reduced in CpG-enriched regions where DNA methylation is more robust. We next tested whether or not DNA methylation was altered at a CpG island within the Pten promoter region following memory retrieval. We collected genomic DNA from CA1 tissue $1 \mathrm{~h}$ after retrieval and performed a meDIP assay with a primer targeting a region that included a $\mathrm{CpG}$ island containing $7 \mathrm{CpG}$ sites, which allowed us to quantify cumulative changes in DNA 5-mc levels within this region (Fig. $1 \mathrm{~g}$ ). Consistent with the reported relationship between DNA methylation and $\mathrm{H} 3 \mathrm{~K} 27 \mathrm{me} 3$ in vitro, we found increased DNA 5-mc levels within the H3K27me3 promoter region $\left(t_{(12)}=2.949, p=0.0122\right)$ that inversely correlated with decreased H3K27me3 levels at this same gene region. Collectively, these results suggest that Pten has increased levels of H3K27me3 and DNA methylation following retrieval.

\section{Pten H3K27me3 levels do not increase following learning or after the retrieval of a remote fear memory}

In the experiments described above, we found that Pten H3K27me3 levels increased in association with reduced PTEN levels in the hippocampus following the retrieval of a contextual fear memory. However, both mTORC1 and histone methylation mechanisms are known to play a critical role in the hippocampus during the initial consolidation of fear memories (Gupta et al., 2010; Gafford et al., 2011; Kerimoglu et al., 2013), suggesting that Pten H3K27me3 levels could increase during both the memory consolidation and reconsolidation processes. To test this idea, we examined whether initial learning triggered increases in Pten H3K27me3 levels in the hippocampus (Fig. 2a). We found that bulk EZH2 $\left(t_{(7)}=2.846, p=0.0248\right)$ and H3K27me3 $\left(t_{(7)}=\right.$ $3.316, p=0.0128$ ) levels were increased in area CA1 $1 \mathrm{~h}$ after training, concurrent with decreases in PTEN $\left(t_{(7)}=3.356, p=\right.$ 0.0122; Fig. $2 b$ ). Surprisingly, despite these bulk increases in H3K27me3 levels, we found no significant learning-dependent changes in H3K27me3 occupancy at the Pten promoter $\left(t_{(7)}=\right.$ $0.6102, p=0.6102)$ or coding $\left(t_{(7)}=0.5788, p=0.5808\right)$ regions (Fig. 2c), suggesting that H3K27me3 levels may be increasing at other genes during the consolidation process. To confirm that EZH2-mediated H3K27me3 was involved in memory consolidation, we infused an Accell siRNA targeting Ezh2 into the CA1 region of the dorsal hippocampus and trained rats to our contextual fear-conditioning protocol (Fig. $2 d$ ). We trained rats $5 \mathrm{~d}$ after siRNA infusion since we observed expression of a green fluorescent control siRNA at this time (Fig. 2e), which correlated with a significant reduction in Ezh2 expression in area CA1 $\left(t_{(13)}=\right.$ $4.405, p=0.0007$; Fig. $2 f$ ). We found that while Ezh2 knockdown did not affect the ability of the rats to acquire the fearconditioning task $\left(t_{(8)}=0.4338, p=0.6759\right.$; Fig. $\left.2 g\right)$, they had impaired memory for the context the following day $\left(t_{(8)}=2.452\right.$, $p=0.0398$; Fig. $2 h$ ), indicating an impaired consolidation process. These results suggest that while EZH2 is critical for memory consolidation, this is potentially independent of increased Pten H3K27me3 levels.

The hippocampus has a time-limited role in the reconsolidation of contextual fear memories, as by $30 \mathrm{~d}$ following acquisition (training) the memory is independent of the hippocampus and requires activity in the ACC region of the medial prefrontal cortex (Frankland et al., 2004; Gräff et al., 2014), although some studies suggest that the hippocampus may continue to be involved even at remote time points (Debiec et al., 2002; Goshen et al., 2011). To test whether increases in H3K27me3 are a general mechanism of memory reconsolidation, we examined whether this histone methylation mark was increased in area CA1 and the ACC following the retrieval of a recent ( $1 \mathrm{~d}$ later) and a remote (30 d later) memory (Fig. 3a,b). We did not find the main effects for retrieval on global $\mathrm{H} 3 \mathrm{~K} 27 \mathrm{me} 3$ levels for either the $\mathrm{CA} 1$ region $\left(F_{(2,14)}=2.237, p=0.1435\right)$ or the $\operatorname{ACC}\left(F_{(2,15)}=1.232, p=\right.$ 
a

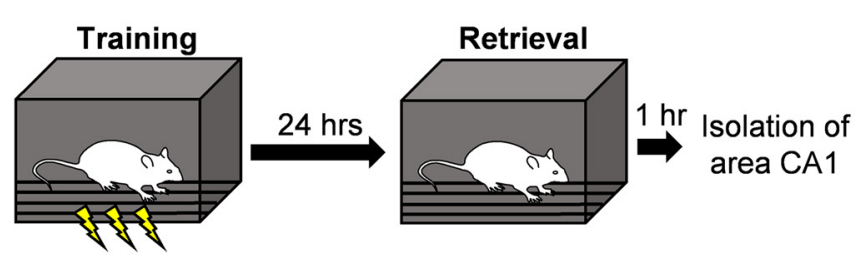

C

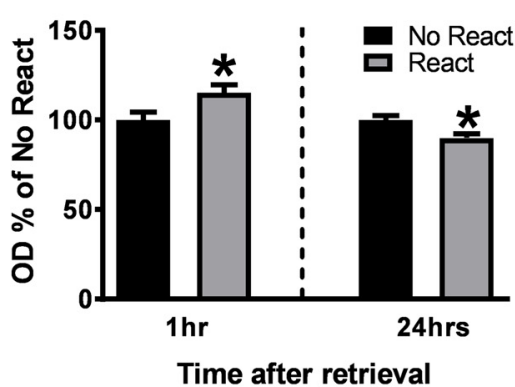

e

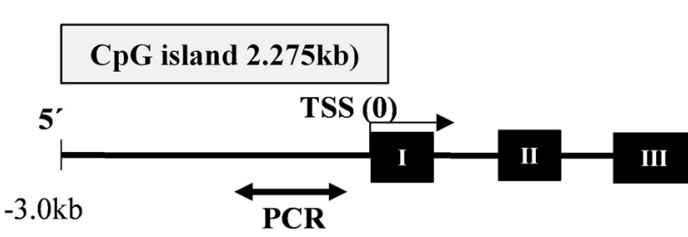

f

ChIP: Pten H3K27me3 levels

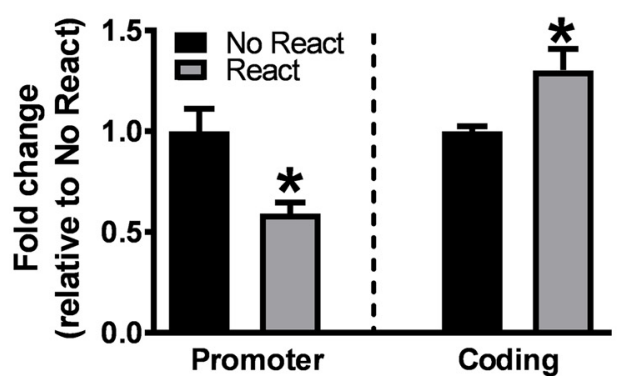

b

EZH2 expression

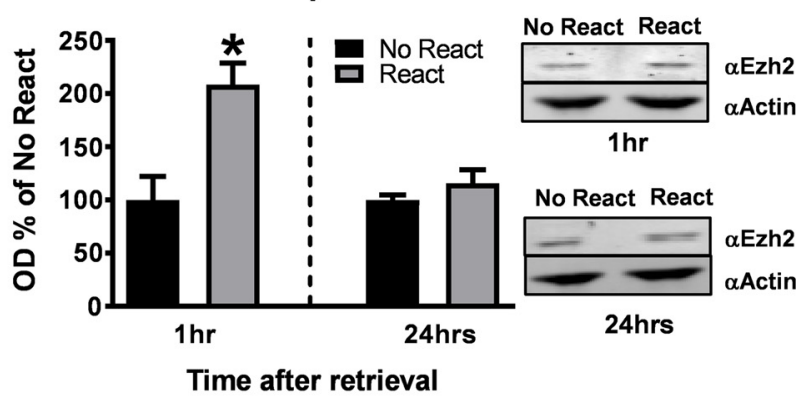

d
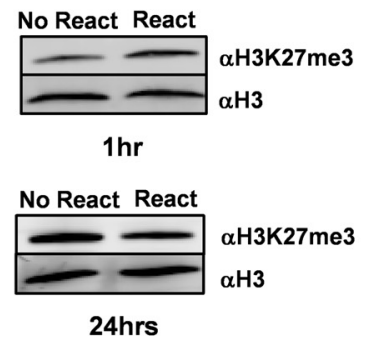

Pten

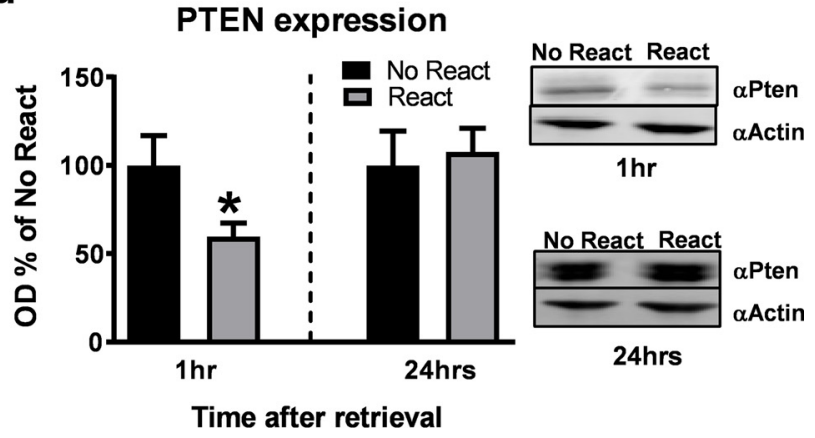

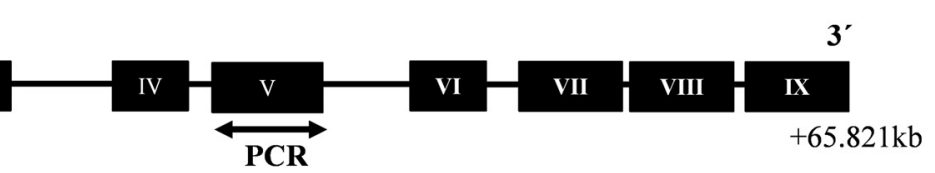

g

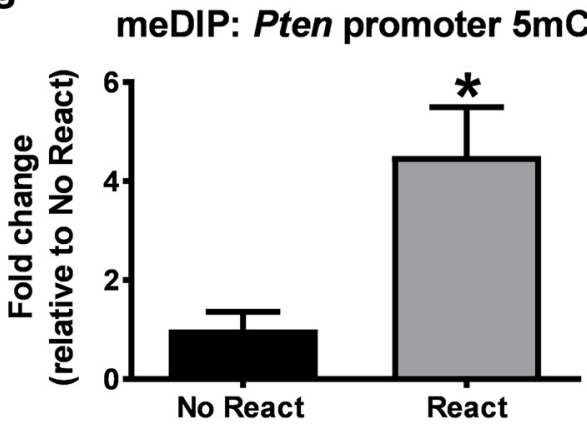

Figure 1. H3K27me3 targets Pten following the retrieval of a newly acquired fear memory. $\boldsymbol{a}$, Experimental design. Rats were trained in context fear conditioning and exposed to the training context the following day. Dorsal CA1 tissue was collected $1 \mathrm{~h}$ after the re-exposure. $\boldsymbol{b}$, EZH 2 levels were increased in area CA1 $1 \mathrm{~h}$ after retrieval and returned to baseline by $24 \mathrm{~h}$ ( $1 \mathrm{~h}: n=4-6 / \mathrm{group}$; $24 \mathrm{~h}: n=8-9 /$ group). $\boldsymbol{c}$, H3K27me3 levels were increased in area CA1 $1 \mathrm{~h}$ after retrieval, but were decreased $24 \mathrm{~h}$ after retrieval ( $1 \mathrm{~h}: n=4-5 / \mathrm{group} ; 24 \mathrm{~h}: n=8-9 / \mathrm{group}) . \boldsymbol{d}, \mathrm{PTEN}$ levels were decreased in area CA $11 \mathrm{~h}$ after retrieval and returned to baseline by $24 \mathrm{~h}(1 \mathrm{~h}: n=5 / \mathrm{group} ; 24 \mathrm{~h}: n=8-10 /$ group).e, Schematics showing PCR targets for ChIP and meDIP experiments. The Pten promoter and coding regions were targeted. $\boldsymbol{f}$, ChIP analysis revealed a decrease in H3K27me3 binding in the promoter but an increase in the coding region of Pten ( $n=6 / g r o u p) . g$, meDIP analysis revealed an increase in DNA 5-methylcystosine in the Pten promoter ( $n=6-8 /$ group). *Denotes $p<0.05$ from No React.

0.3195). To test whether this was due to differential H3K27me3 changes between recent and remote retrieval groups, we performed pairwise $t$ tests comparing the retrieval condition (recent or remote) to the no-retrieval control group. We found increases in $\mathrm{H} 3 \mathrm{~K} 27 \mathrm{me} 3$ levels in bulk histone extracts from area CA1 following the retrieval of a recent $\left(t_{(9)}=2.681, p=0.0252\right)$, but not a remote $\left(t_{(10)}=0.02257, p=0.9824\right)$, contextual fear memory (Fig. $3 c$ ). This is consistent with the idea of "systems consolidation" where the memory becomes independent of the hippocampus with time, instead being stored in extrahippocampal sites such as the prefrontal cortex (Winocur and Moscovitch, 2011).
Surprisingly, we did not observe increases in $\mathrm{H} 3 \mathrm{~K} 27 \mathrm{me} 3$ in the ACC following the retrieval of a recent $\left(t_{(10)}=1.242, p=0.2425\right)$ or a remote $\left(t_{(10)}=1.530, p=0.1571\right)$ fear memory, even though we have previously shown that c-Fos and Npas4 protein levels are increased in this region following remote memory retrieval, indicating that the ACC is engaged during the reconsolidation process (Webb et al., 2017). To examine this further, we performed ChIP assays on CA1 and ACC tissue collected $1 \mathrm{~h}$ after the retrieval of a remote contextual fear memory. ChIP analysis on the ACC supported our bulk histone extract data, as we observed no significant alterations in $\mathrm{H} 3 \mathrm{~K} 27 \mathrm{me} 3$ levels at the Pten promoter 
a

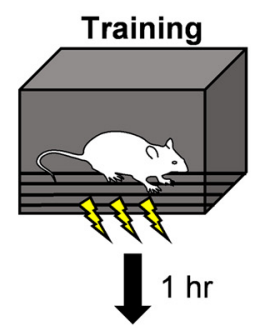

Isolation of area CA1 b

\section{Protein expression in CA1}

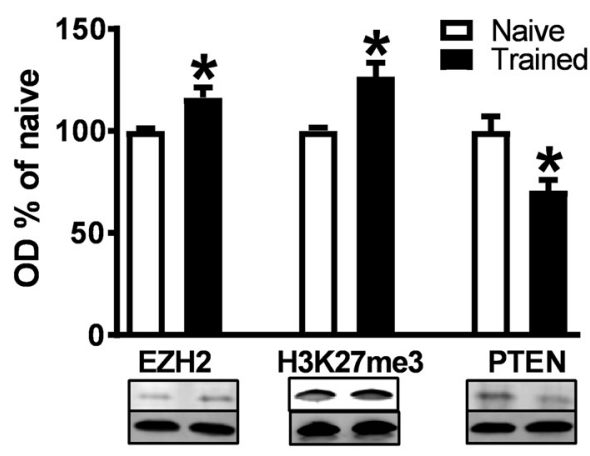

C

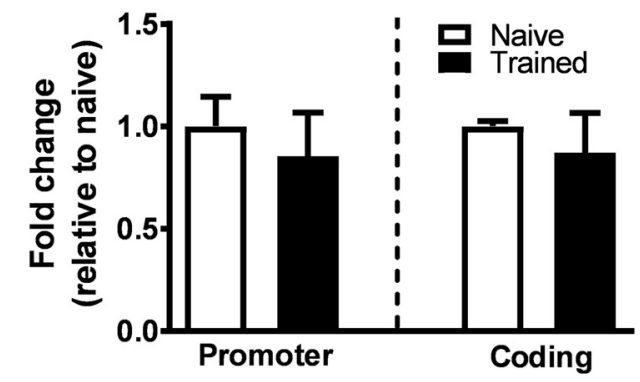

d

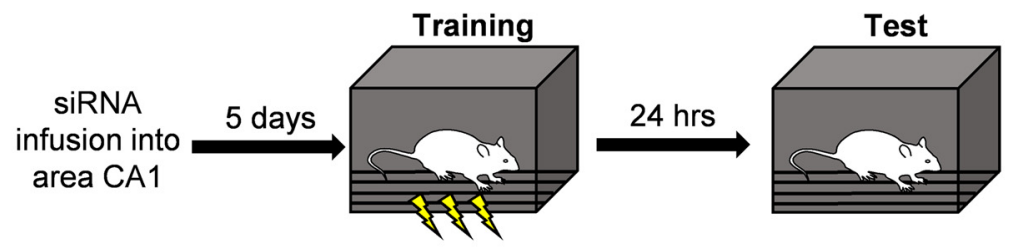

e

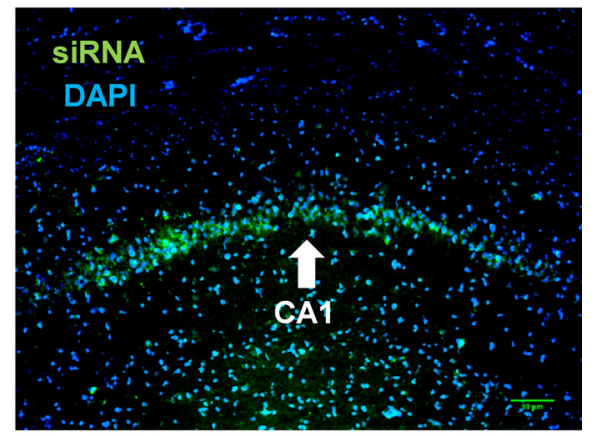

h

f

g

Performance during training
Retention during test
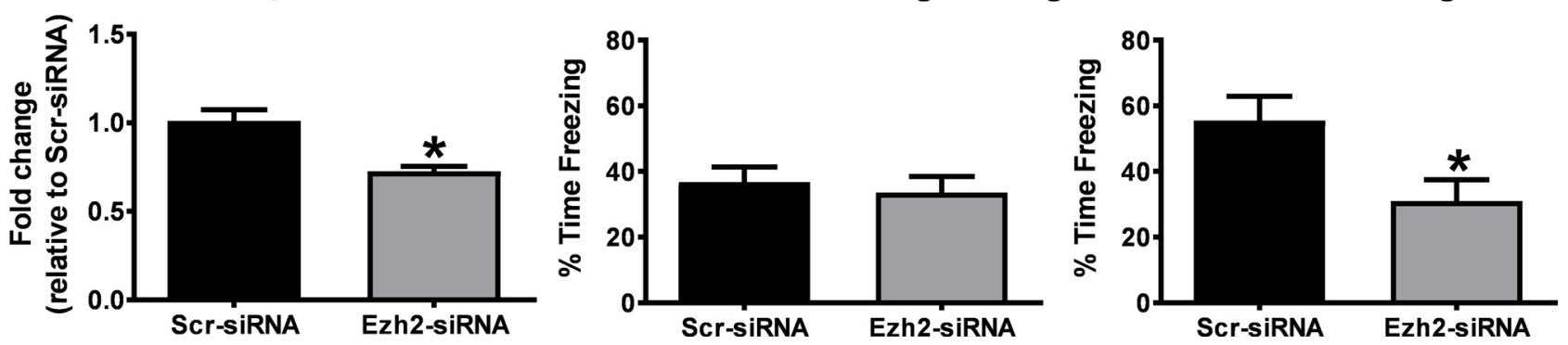

Figure 2. H3K27me3 does not target Pten during memory consolidation. $\boldsymbol{a}$, Experimental design for $\boldsymbol{b}$ and $\boldsymbol{c}$. Rats were trained in context fear conditioning, and dorsal CA1 tissue was collected $1 \mathrm{~h}$ later. $\boldsymbol{b}$, EZH2 and H3K27me3 levels were increased in area CA1 $1 \mathrm{~h}$ after training while PTEN was reduced ( $n=4-5 /$ group). Bottom, Representative Western blot images are actin (for EZH2 and PTEN) and H3 (for H3K27me3). c, ChIP analysis did not reveal any changes in H3K27me3 binding in the Pten promoter or coding regions ( $n=4-5 / g r o u p) . \boldsymbol{d}$, Experimental design for $\boldsymbol{e}-\boldsymbol{h}$. Rats were injected with Accell siRNA targeting Ezh 2 or control $5 \mathrm{~d}$ before contextual fear conditioning and tested the following day ( $n=4-6 /$ group). $\boldsymbol{e}$, Expression of a green fluorescent control Acell siRNA in CA1 cells $5 \mathrm{~d}$ after infusion. $\boldsymbol{f}$, qRT-PCR analysis showing reduction of Ezh2 $\mathrm{mRNA}$ at baseline in area CA1 following siRNA infusion ( $n=7-8 / \mathrm{group})$. $\boldsymbol{g}, \boldsymbol{h}$, Knockdown of Ezh2 in area CA1 did not affect the ability of the rats to acquire the context-shock association $(\boldsymbol{g})$, but memory for the task was impaired when tested the following day $(\boldsymbol{h}) .{ }^{*} p<0.05$ from control (Naive or $S \mathrm{cr}$-siRNA).

$\left(t_{(6)}=0.2118, p=0.8393\right)$ or coding $\left(t_{(6)}=1.610, p=0.1585\right)$ regions (Fig. 3d), suggesting that Pten $\mathrm{H} 3 \mathrm{~K} 27 \mathrm{me} 3$ levels did not change during the reconsolidation of a remote fear memory. Furthermore, CA1 H3K27me3 promoter $\left(t_{(5)}=0.9692, p=0.3770\right)$ and coding $\left(t_{(5)}=1.575, p=0.1761\right.$; Fig. $3 e$ ) levels and ACC PTEN protein levels $\left(t_{(10)}=0.4724, p=0.6468\right.$; Fig. $\left.3 f\right)$ remained unchanged following the retrieval of a remote memory. Collectively, these results suggest that Pten $\mathrm{H} 3 \mathrm{~K} 27 \mathrm{me} 3$ levels, and possibly overall increases in $\mathrm{H} 3 \mathrm{~K} 27 \mathrm{me} 3$, are specific to the retrieval of a new fear memory.

Knockdown of Ezh2 in the hippocampus abolishes increases in $\mathrm{H} 3 \mathrm{~K} 27 \mathrm{me} 3$ and decreases in PTEN following retrieval Having established that increases in $\mathrm{H} 3 \mathrm{~K} 27 \mathrm{me} 3$ were specific to the retrieval of a new fear memory, we next tested whether H3K27me3 was necessary for Pten repression during the reconsolidation process. We trained rats to contextual fear condition- ing and $24 \mathrm{~h}$ later performed intracranial brain surgeries where we infused an Accell siRNA targeting Ezh2 into the CA1 region of the dorsal hippocampus. Rats were allowed to recover from surgeries and optimal transfection of Ezh2-siRNA and Scrambled-siRNA (nontargeting) for $5 \mathrm{~d}$. Rats were then reexposed to the training context to reactivate the memory, and at $1 \mathrm{~h}$ area CA1 of the dorsal hippocampus was collected (Fig. $4 a$ ). Accordingly, while the Ezh2-siRNA did not prevent memory retrieval (Fig. $4 b$ ), we were able to successfully reduce EZH2 in area CA1 $\left(F_{(2,13)}=6.063, p=0.0138\right)$ but not the overlying cortical layer $\left(F_{(2,13)}=0.6271, p=0.5495\right.$; Fig. $\left.4 c\right)$ supporting that the Ezh2-siRNA infusion was largely localized to the hippocampus. Consistent with the loss of EZH2, we found that the Ezh2-siRNA abolished retrieval-induced increases in $\mathrm{H} 3 \mathrm{~K} 27 \mathrm{me} 3$ in area CA1 $\left(F_{(2,13)}=6.832, p=0.0094\right.$; Fig. $4 d)$ and prevented reductions in PTEN levels following retrieval $\left(F_{(2,13)}=4.722, p=0.0287\right.$; Fig. $\left.4 e\right)$. Collectively, 
a

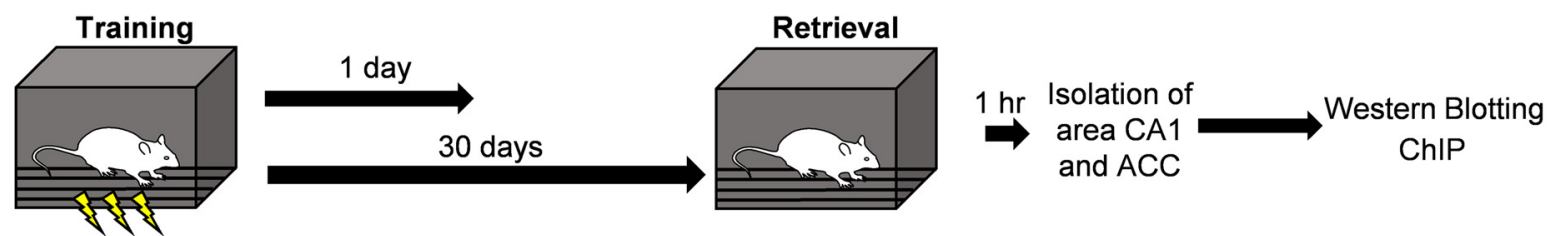

b

\section{Retention during retrieval}

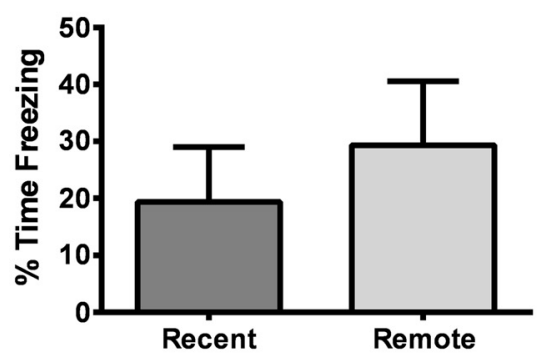

d

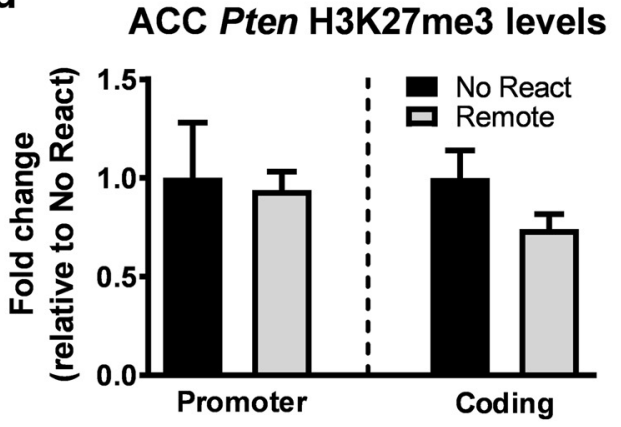

C

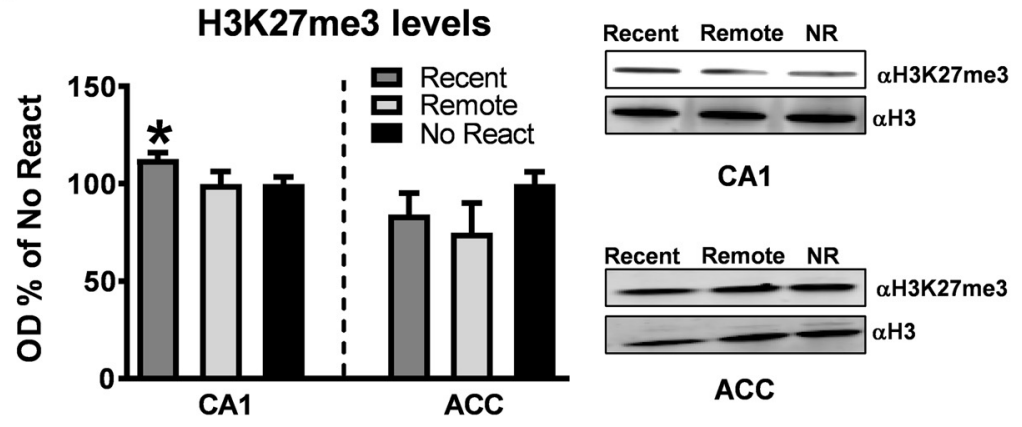

e CA1 Pten H3K27me3 levels f

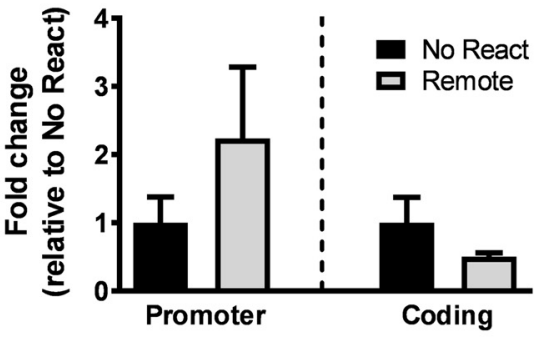

ACC PTEN levels

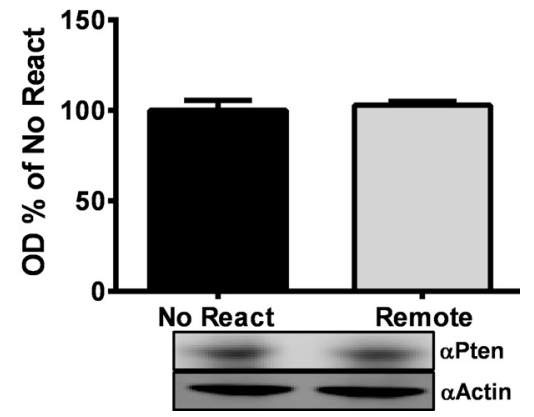

Figure 3. H3K27me3 does not target Pten following the retrieval of a remote memory. $\boldsymbol{a}$, Experimental design. Rats were trained in context fear conditioning and exposed to the training context 1 or $30 \mathrm{~d}$ later. Dorsal CA1 and ACC tissue were collected $1 \mathrm{~h}$ after the re-exposure. $\boldsymbol{b}$, There were no differences in memory retention during the retrieval of a new (recent) or old (remote) fear memory. c, H3K27me3 levels were increased in area CA1 $1 \mathrm{~h}$ after the retrieval of a recent, but not a remote, fear memory. H3K27me3 levels in bulk histone extracts were not significantly changed in the ACC following retrieval ( $n=5-6 /$ group for $\mathrm{CA}$; $n=6 /$ group for $\mathrm{ACC})$. $\boldsymbol{d}, \boldsymbol{e}, \mathrm{ChIP}$ analysis did not reveal any changes in H3K27me3 binding at the Pten promoter or coding regions in the $\mathrm{ACC}(\boldsymbol{d})$ or $\mathrm{CA} 1$ (e) following the retrieval of a remote fear memory $\left(n=3-4\right.$ /group). $f$, Pten levels were not changed in the ACC following remote memory retrieval. $(n=6 /$ group $) .{ }^{*} p<0.05$, from No React.

these results indicate that Ezh2-mediated $\mathrm{H} 3 \mathrm{~K} 27 \mathrm{me} 3$ is involved in Pten repression during memory reconsolidation.

Loss of H3K27me3-induced Pten repression prevents increases in AKT-mTORC1 phosphorylation following retrieval

Since PTEN is a potent antagonist of the PI3K-AKT-mTORC1 pathway, we next tested whether a loss of H3K27me3 following retrieval altered previously reported increases in mTOR phosphorylation (Gafford et al., 2011). While we did not find a main effect for Ezh2-siRNA manipulation on the phosphorylation of $\operatorname{AKT}\left(F_{(2,12)}=1.531, p=0.2556\right)$, we did observe a retrievaldependent increase in AKT phosphorylation $\left(t_{(7)}=2.543, p=\right.$ 0.0385; No React vs Scr-siRNA React) that was not present following Ezh2 knockdown $\left(t_{(9)}=0.5439, p=0.5998\right.$; No react vs Ezh2-siRNA React; Fig. 4f). Furthermore, phosphorylatedmTOR levels were significantly affected by Ezh2 knockdown $\left(F_{(2,13)}=4.474, p=0.0332\right.$; Fig. $\left.4 g\right)$ as we found that increases in mTOR phosphorylation following retrieval $\left(t_{(8)}=3.362, p=\right.$ 0.0099 , No React vs Scr-siRNA React) were completely reversed by Ezh 2 knockdown $\left(t_{(9)}=2.680, p=0.0252\right.$, Scr-siRNA React vs Ezh2-siRNA React), an effect we confirmed with an mTOR
ELISA $\left(F_{(2,13)}=6.110, p=0.0135\right.$; Fig. $\left.4 h\right)$. Since our phosphomTOR antibodies do not distinguish between mTORC1 and mTORC2, we next tested the effect of Ezh2 knockdown on the phosphorylation of the mTORC1 substrate P70S6K following retrieval. We found a main effect for levels of phosphorylated P70S6K $\left(F_{(2,12)}=6.683, p=0.0112\right.$; Fig. 4i). While retrieval increased levels of phosphorylated P70S6K $\left(t_{(7)}=2.625, p=\right.$ 0.0171, No React vs Scr-siRNA React), this was completely lost following Ezh2 knockdown $\left(t_{(8)}=3.441, p=0.0088\right.$, Scr-siRNA React vs Ezh2-siRNA React), supporting that mTORC1 activity was altered by the loss of $\mathrm{H} 3 \mathrm{~K} 27 \mathrm{me} 3$. Collectively, these results strongly suggest that EZH2-mediated $\mathrm{H} 3 \mathrm{~K} 27$ me3 regulates Pten repression and AKT-mTORC1 phosphorylation during memory reconsolidation.

H3K27me3 regulates Pten gene repression necessary for AKT-mTORC1 phosphorylation following retrieval Thus far, our experiments provide evidence supporting that EZH2-mediated H3K27me3 is critical for AKT-mTORC1 phosphorylation following retrieval. However, we have not yet determined whether or not $\mathrm{H} 3 \mathrm{~K} 27 \mathrm{me} 3$ transcriptional repression of Pten couples with AKT-mTORC1. To directly test this relation- 
a

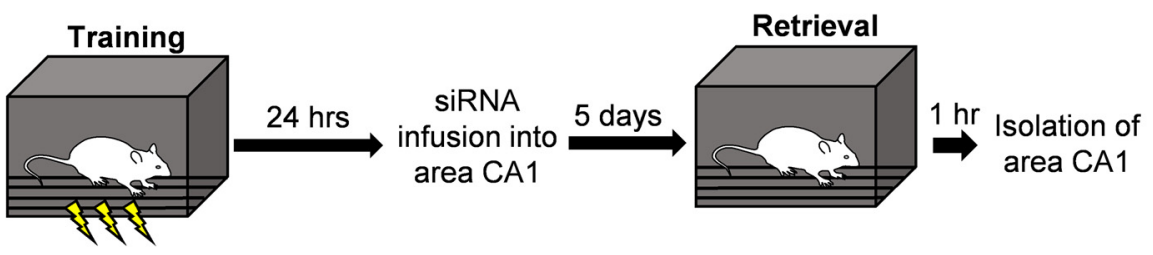

C

EZH2 levels

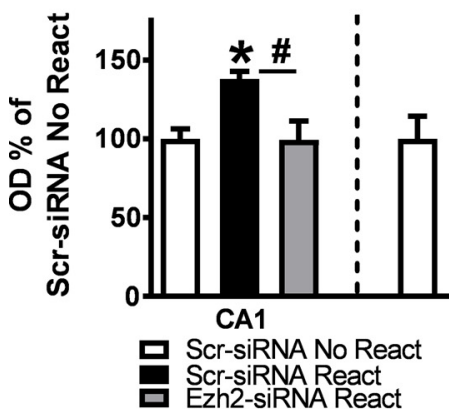

e

PTEN levels

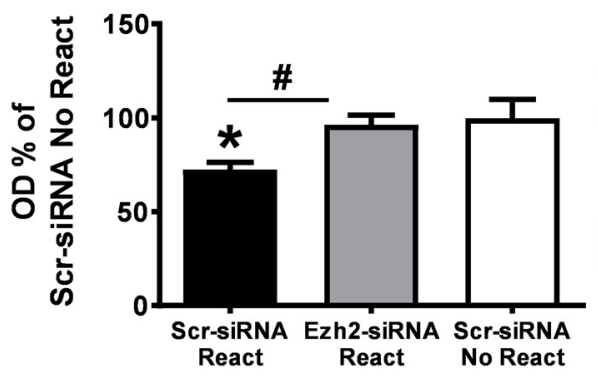

g

phospho-mTOR levels
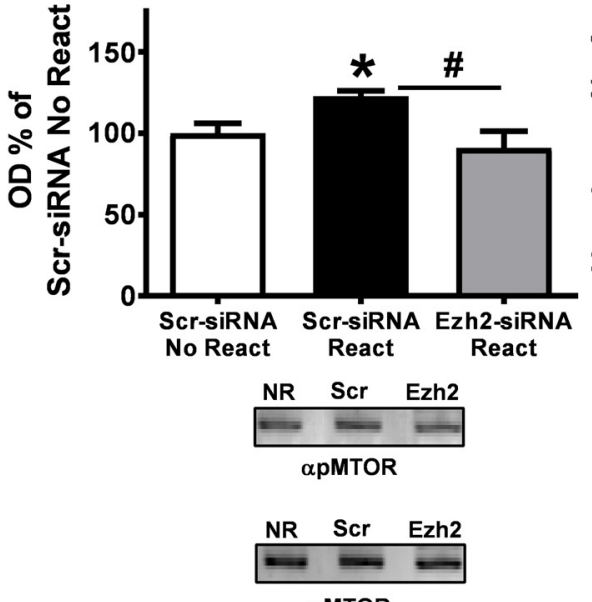

f

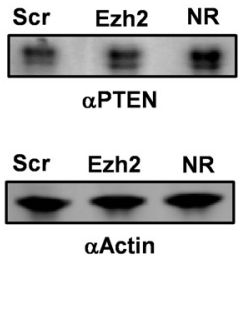

h

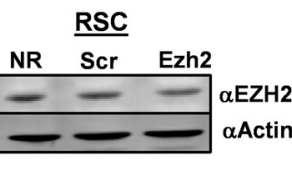

ELISA: phospho-mTOR

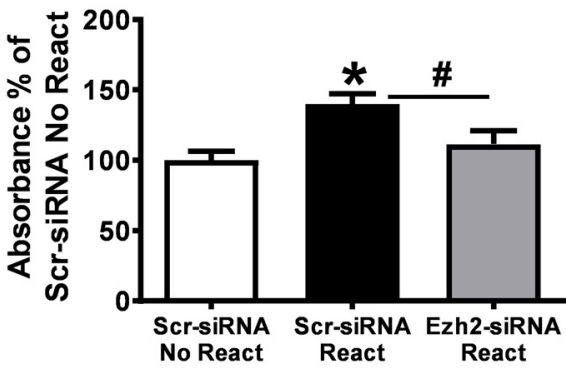

b Retention during retrieval

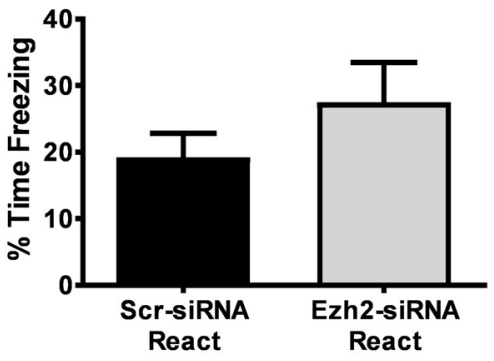

H3K27me3 levels

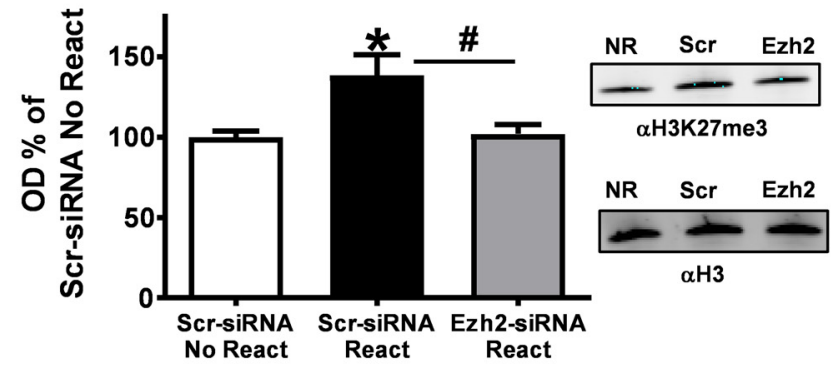

Phospho-AKT(Thr-308) levels

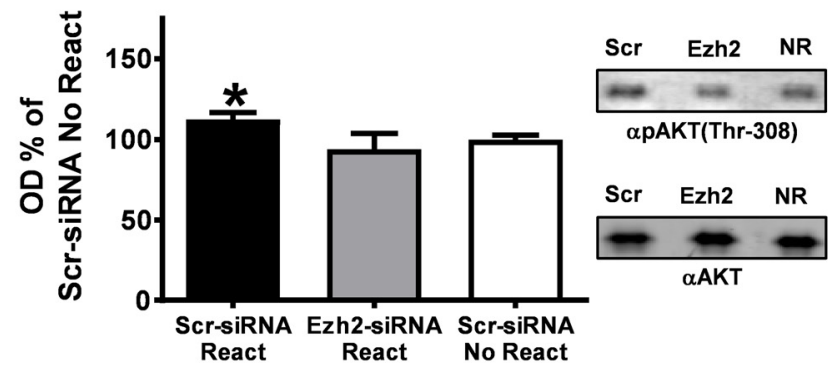

phospho-P70S6K levels
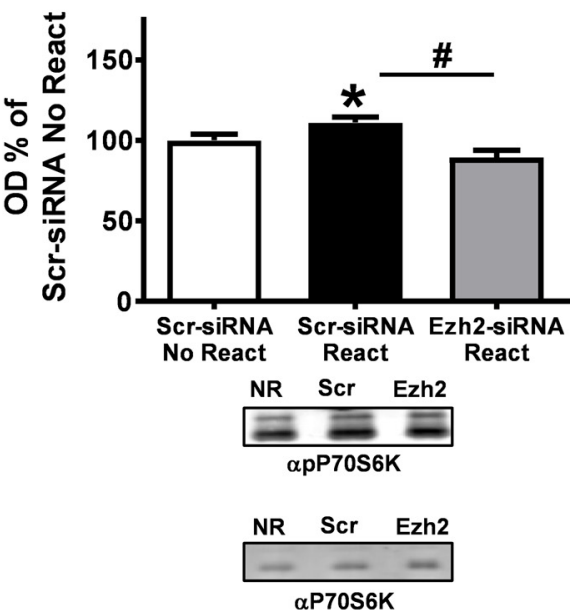

Figure 4. H3K27me3 regulates Pten repression and AKT-mTORC1 phosphorylation following retrieval. $\boldsymbol{a}$, Experimental design. Rats were trained in context fear conditioning, and the following day received bilateral injections of Accell siRNA against Ezh2 into area CA1 (Ezh2-siRNA); a scrambled siRNA sequence was used as a control (Scr-siRNA). Five days later, rats were exposed to the training context and dorsal CA1 tissue was collected $1 \mathrm{~h}$ later ( $n=5-6 /$ group). $\boldsymbol{b}$, Infusion of Ezh2-siRNA did not alter retrieval of the memory. $\boldsymbol{c}$, EZH2 levels were increased in area CA1 $1 \mathrm{~h}$ after retrieval, which was blocked by the Ezh2-siRNA. There were no changes in EZH2 in the RSC. $\boldsymbol{d}, \mathrm{H3}$ K27me3 levels were increased in area CA1 $1 \mathrm{~h}$ after retrieval, which was blocked by infusion of the Ezh2-siRNA. e, PTEN levels were decreased in area CA1 $1 \mathrm{~h}$ after retrieval, which was prevented by the Ezh2-siRNA.f, Retrieval increased phosphorylation of AKT at Thr-308, which was lost following Ezh2 knockdown. $\boldsymbol{g}, \boldsymbol{h}$, Western blot analysis $(\boldsymbol{g})$ and ELISA $(\boldsymbol{h})$ revealed that retrieval-induced increases in mTORC1 phosphorylation were lost following Ezh2 knockdown. $\boldsymbol{i}$, Ezh $2 \mathrm{knockdown}$ reduced phosphorylation of the P70S6 kinase in area CA1 following retrieval. ${ }^{*} p<0.05$, from Scr-siRNA No React. $\# p<0.05$, from scr-siRNA React. 
a

\begin{tabular}{|c|c|c|c|c|c|c|}
\hline & \multicolumn{6}{|c|}{ Effect on protein (relative to baseline) } \\
\hline & & & H3K27me3 & Pten & Phospho-AKT & Phospho-mTOR1 \\
\hline & Retrieval & 1 & 1 & W & 1 & 1 \\
\hline & 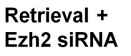 & \ & Љ & 1 & b & 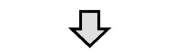 \\
\hline$\frac{5}{\pi}$ & $\begin{array}{l}\text { Retrieval + } \\
\text { Ezh2 and } \\
\text { Pten siRNAs }\end{array}$ & Љ & Z & Ð & & \\
\hline
\end{tabular}

C

d b

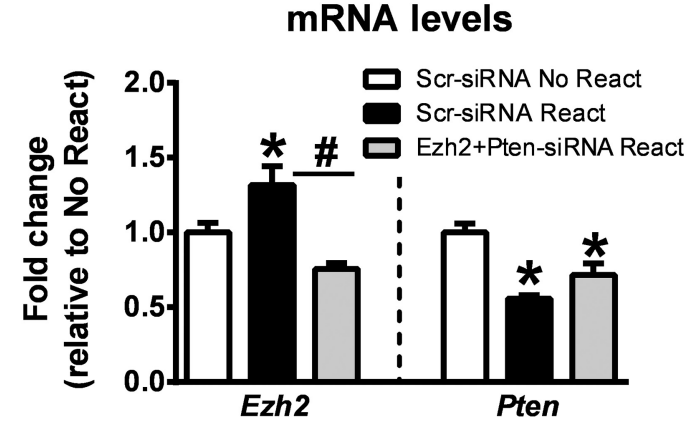

\section{H3K27me3 levels}

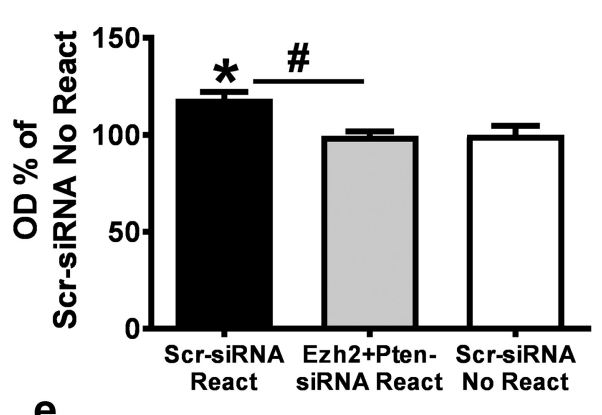

e

phospho-mTORC1 levels

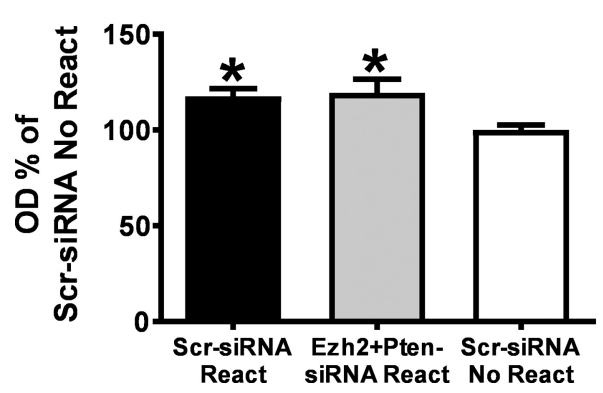

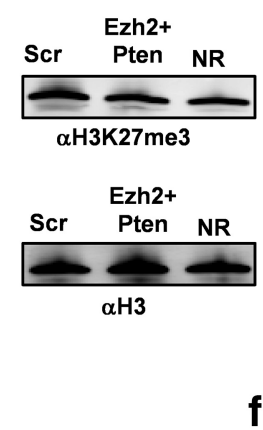

f
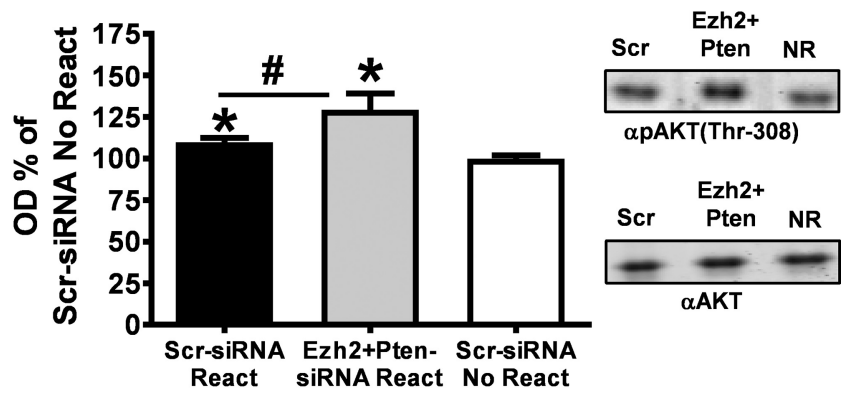

\section{ELISA: phospho-mTORC1}
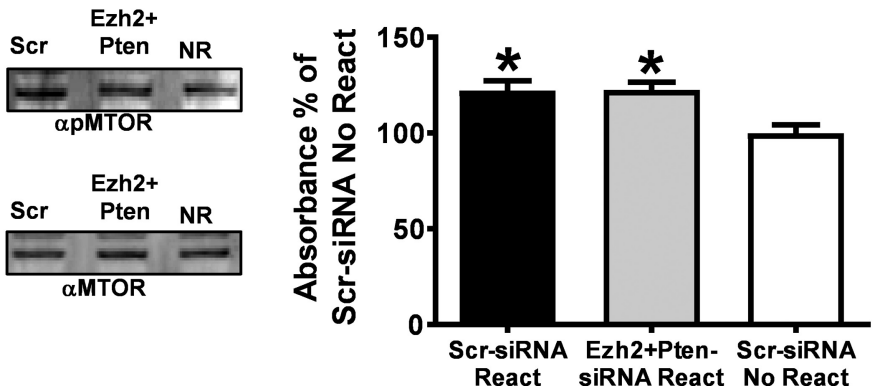

Figure 5. H3K27me3 regulates AKT-mTORC1 phosphorylation following retrieval via repression of Pten. Rats were trained in context fear conditioning, and the following day received bilateral injections of Accell siRNAs against Ezh2 and Pten (Ezh2 + Pten-siRNA) into area CA1; a scrambled siRNA sequence was used as a control (Scr-siRNA). Five days later, rats were exposed to the training context and dorsal CA1 tissue was collected $1 \mathrm{~h}$ later. $\boldsymbol{a}$, Predictions for the effect of double-gene knockdown experiment. $\boldsymbol{b}$, Retrieval increased Ezh2 expression, which was prevented by the infusion of the Ezh2 + Pten-siRNA. Pten levels were reduced following retrieval, which was not altered by the Ezh2 + Pten-siRNA ( $n=4-6 /$ group). c, H3K27me3 levels were increased in area CA1 $1 \mathrm{~h}$ after retrieval, which was blocked by the Ezh2 + Pten-siRNA ( $n=5-6 /$ group). $\boldsymbol{d}$, Phosphorylated AKT(Thr-308) levels were increased in area CA1 $1 \mathrm{~h}$ after retrieval, which was further enhanced by infusion of the Ezh2 + Pten-siRNA ( $n=5-6 /$ group). $\boldsymbol{e}, \boldsymbol{f}$, Western blot analysis $(\boldsymbol{e})$ and ELISA $(\boldsymbol{f})$ revealed that phosphorylated mTORC1 levels were increased in area CA1 $1 \mathrm{~h}$ after retrieval, which was not affected by the Ezh2 + Pten-siRNA ( $n=5-6 /$ group). ${ }^{*} p<0.05$, from Scr-siRNA No React. $\# p<0.05$, from scr-siRNA React.

ship, we simultaneously reduced Ezh2 and Pten gene expression in area CA1 and examined AKT-mTORC1 phosphorylation during the postretrieval period. This allowed us to prevent the increases in PTEN levels that we observed following Ezh2 knockdown in our previous experiment (Fig. 5a). Consistent with our targeting of Ezh2, we found a loss of retrieval-induced increases in Ezh2 expression following infusion of the Ezh2 + Pten siRNA $\left(F_{(2,12)}=9.285, p=0.0037\right.$; Fig. $\left.5 b\right)$. Pten expression was significantly reduced following both retrieval and infusion of the Ezh2 + Pten siRNA $\left(F_{(2,12)}=16.94, p=0.0003\right)$. Furthermore, knockdown of Ezh2 and Pten resulted in reduced EZH2 and PTEN protein levels as we found that the retrieval-dependent increases in $\mathrm{H} 3 \mathrm{~K} 27 \mathrm{me} 3\left(F_{(2,14)}=8.848, p=0.0033\right.$; Fig. $\left.5 c\right)$ were lost while the increases in phosphorylated AKT were preserved $\left(F_{(2,14)}=5.591, p=0.0164\right.$; Fig. $\left.5 d\right)$ in the Ezh2 + Pten siRNA group. Thus, we were able to sufficiently reduce both EZH2 and PTEN activity within the same samples. Additionally, we observed a significant increase in mTOR phosphorylation following retrieval in control siRNA-injected rats relative to no-retrieval controls $\left(F_{(2,14)}=4.466, p=0.0316\right.$; Fig. $\left.5 e\right)$, which was also present in the Ezh2 + Pten siRNA-injected rats even though retrieval-induced increases in $\mathrm{H} 3 \mathrm{~K} 27$ me3 were lost. Furthermore, we confirmed this result with an mTOR ELISA $\left(F_{(2,15)}=\right.$ $8.450, p=0.0035$; Fig. $5 f$ ), supporting that we rescued deficits in mTOR phosphorylation that occur following the loss of H3K27me3. Collectively, these results provide evidence suggesting that retrieval-induced EZH2 regulates mTORC1 phosphorylation through $\mathrm{H} 3 \mathrm{~K} 27$ me3-mediated transcriptional repression of Pten in the hippocampus. 
a
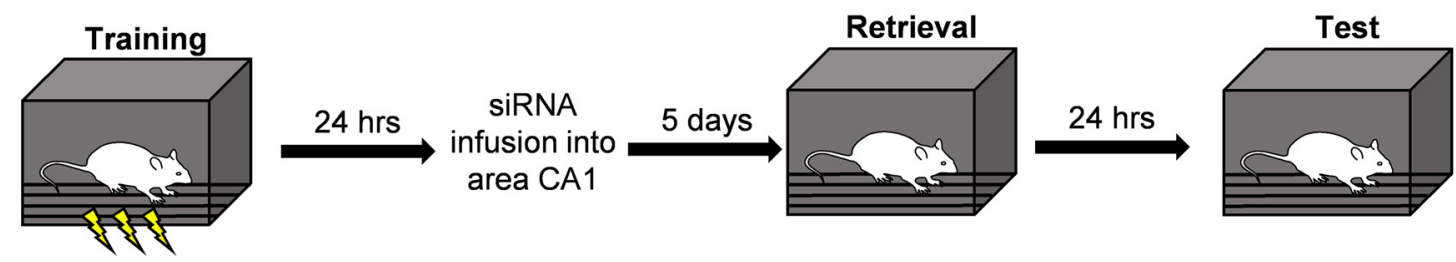

b

Performance during training

C Retention during retrieval

d

Retention during test
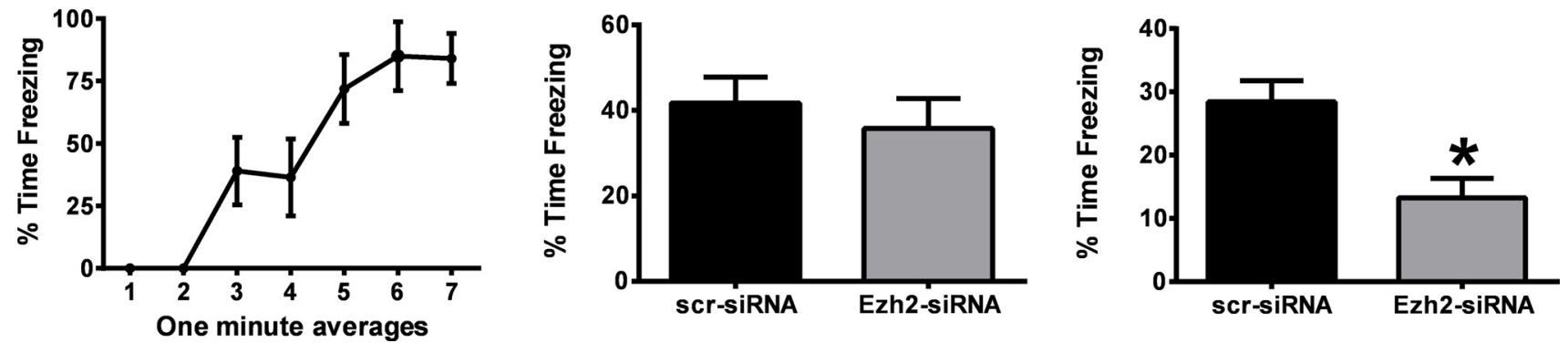

Figure 6. H3K27me3 is critical for memory reconsolidation following retrieval. $\boldsymbol{a}$, Experimental design. Rats were trained in context fear conditioning, and the following day received bilateral injections of Accell siRNA against Ezh2 (Ezh2-siRNA) into area (A1; a scrambled siRNA sequence was used as a control (Scr-siRNA). Five days later, rats were exposed to the training context, and the day after tested for long-term memory for the context-shock association ( $n=7-8 /$ group). $\boldsymbol{b}-\boldsymbol{d}$, All rats acquired the task normally ( $\boldsymbol{b}$ ) and their memory for the task was not altered by the siRNA infusions before retrieval (c); however, they showed significant impairments in memory for the task during the final test $(\boldsymbol{d}) .{ }^{*} p<0.05$, from Scr-siRNA.

H3K27me3 is a critical regulator of memory reconsolidation following retrieval

Pharmacological inhibition of mTORC1 activation impairs the memory reconsolidation process (Parsons et al., 2006; Gafford et al., 2011; Jobim et al., 2012; Mac Callum et al., 2014). Since we observed a loss of mTORC1 phosphorylation following Ezh2 knockdown, we next wanted to test whether increases in H3K27me3 were critical for memory reconsolidation following retrieval (Fig. $6 a$ ). All rats acquired the task $\left(t_{(13)}=0.2682, p=\right.$ 0.7927; Fig. $6 b)$, and their retention for it was not altered by the Ezh2-siRNA infusion procedure $\left(t_{(13)}=0.6323, p=0.5382\right.$; Fig. $6 c$ ). However, rats receiving the Ezh2-siRNA had significant memory impairments on a later test day $\left(t_{(13)}=3.319, p=\right.$ 0.0055; Fig. $6 d$ ), suggesting that increases in H3K27me3 were critical for memory reconsolidation. In Figure 7, we summarize our results indicating that EZH2-mediated increases in $\mathrm{H} 3 \mathrm{~K} 27 \mathrm{me} 3$ regulate Pten repression and mTORC1 phosphorylation and memory stability following retrieval (Fig. 7).

\section{Discussion}

While it has been strongly supported that increased translational control in memory-related brain regions is necessary for memory reconsolidation (Milekic and Alberini, 2002; Debiec et al., 2002; Lattal and Abel, 2004), exactly how this requirement for de novo protein synthesis is regulated following retrieval remains equivocal. Furthermore, though a number of studies have implicated epigenetic mechanisms in transcriptional regulation during the reconsolidation process (Lubin and Sweatt, 2007; Bredy and Barad, 2008; Maddox and Schafe, 2011), very little is known about the downstream signaling cascades that are affected by these modifications following retrieval. In the present study, we found that the retrieval of a contextual fear memory increased H3K27me3-mediated repression of Pten in the hippocampus. Importantly, knockdown of the H3K27me3 methyltransferase Ezh2 prevented the retrieval-induced loss of Pten and abolished increases in AKT-mTORC1 phosphorylation, which could be restored by simultaneous knockdown of Pten. Collectively, these results reveal a novel epigenetic mechanism of the memory reconsolidation process and demonstrate that retrieval-induced activation of the AKT-mTORC1 pathway requires intricate epigenetic-mediated repression of Pten.

\section{A selective involvement of $\mathrm{H} 3 \mathrm{~K} 27 \mathrm{me} 3$ in $\mathrm{PTEN}$ regulation} during the reconsolidation of a recent fear memory Interestingly, while we did observe increases in $\mathrm{H} 3 \mathrm{~K} 27 \mathrm{me} 3$ with concurrent decreases in PTEN levels following both learning and memory retrieval, Pten H3K27me3 levels only increased during the reconsolidation process. This result is particularly surprising since it suggests that this mechanism of Pten repression may be unique to the reconsolidation process. While cellular reconsolidation is largely considered to not be a recapitulation of consolidation (Alberini, 2005), to date, only a few mechanisms have been implicated as being differentially involved in the consolidation and reconsolidation of a given memory (Taubenfeld et al., 2001; Lee et al., 2004, 2008; Milekic et al., 2007). Our present results add to this growing literature by demonstrating novel genes regulated by $\mathrm{H} 3 \mathrm{~K} 27 \mathrm{me} 3$ in the consolidation and reconsolidation processes and add a new dimension to these unique mechanisms as, to the best of our knowledge, we show for the first time that the levels of a specific enzyme (PTEN) are differentially regulated during the consolidation and reconsolidation processes. Consistent with this, PTEN is regulated at the transcriptional, translational, and post-translational levels (Kreis et al., 2014), suggesting that PTEN could be regulated by a different mechanism during the consolidation process. However, an alternative explanation is that Pten $\mathrm{H} 3 \mathrm{~K} 27$ me3 levels increase during memory consolidation, although the temporal dynamics of this may differ from reconsolidation as some cellular mechanisms have shown different time courses for their regulation following learning and retrieval. While we cannot completely rule out this interpretation, it is unlikely, because we found that even though EZH2 and H3K27me3 levels were elevated simultaneously with PTEN reductions following training, Pten $\mathrm{H} 3 \mathrm{~K} 27 \mathrm{me} 3$ levels did not change, suggesting that if $\mathrm{H} 3 \mathrm{~K} 27 \mathrm{me} 3$ were transcriptionally 


\section{Before retrieval}

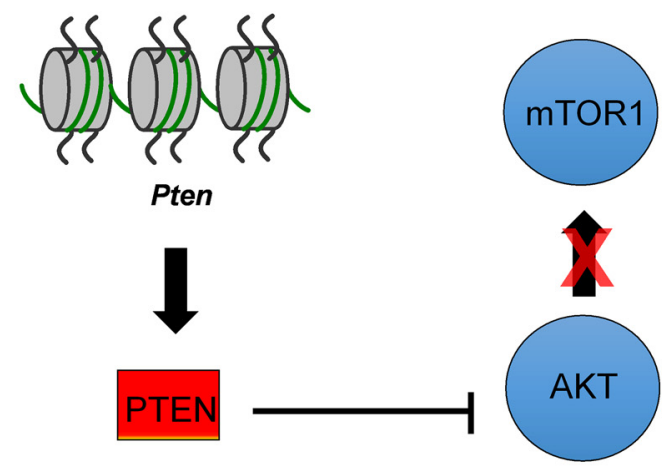

\section{After retrieval}
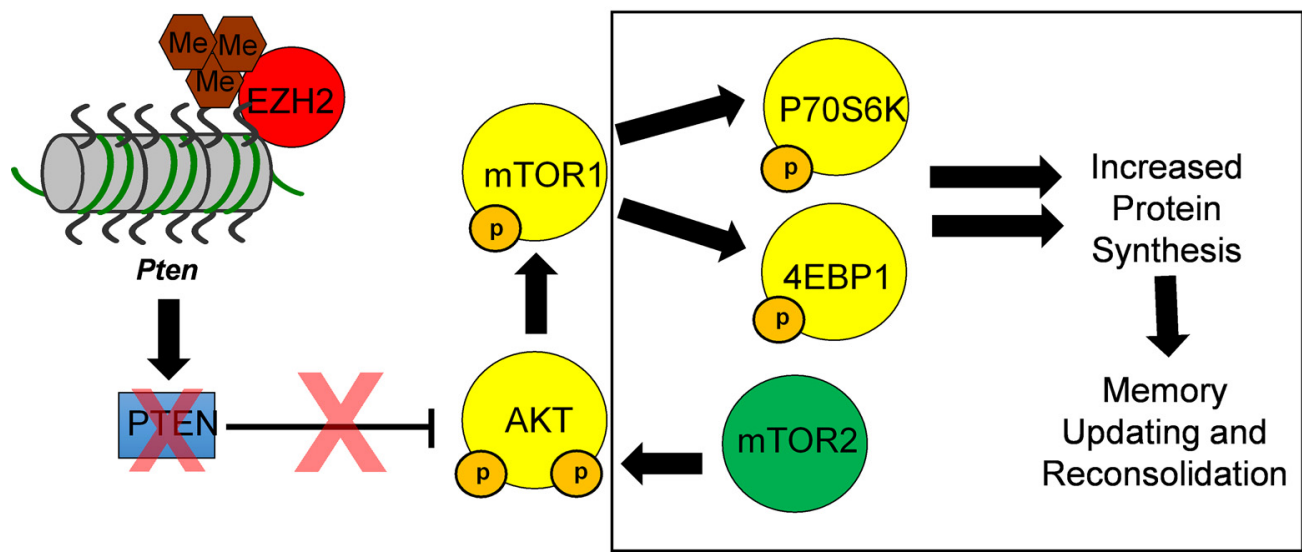

Figure 7. Hypothetical model for how H3K27me3 regulates mTORC 1 activation following retrieval. Before retrieval, Pten is transcribed, which limits the amount of phosphorylated mTORC1 by preventing the phosphorylation of AKT. After retrieval, EZH2 binds to chromatin around the Pten gene, where it trimethylates H3 lysine 27. This leads to closing of the chromatin structure and transcriptional repression of Pten. As a result, AKT becomes phosphorylated, which leads to activation of mTORC1. This should then lead to increased phosphorylation of downstream mTOR substrates that previously were reported to be critical for the memory storage processes (signified in boxed area).

silencing Pten during the consolidation process, we would have still been able to see that at the time point examined. Future studies should aim to more precisely determine how PTEN is regulated during the consolidation process and whether this occurs through transcriptional repression (i.e., DNA methylation) or changes in protein turnover (ubiquitin-proteasome signaling).

Another interesting result from our study was that the repression of Pten by H3K27me3 only occurred following the retrieval of a memory for a newly learned association. This result is surprising since epigenetic mechanisms have recently been implicated in the reconsolidation of remote fear memories (Miller et al., 2010; Gräff et al., 2014). Furthermore, we did not observe changes in PTEN levels in the ACC following remote memory retrieval, although phosphorylation of the mTORC1 substrate P70S6K is increased in this region during the reconsolidation of older fear memories (Gafford et al., 2013). This suggests that mTOR-mediated protein synthesis may not require the repression of Pten during remote memory reconsolidation, although it is unclear how this would occur. However, P70S6K can also be phosphorylated by ERK-MAPK signaling (Herbert et al., 2000), suggesting that ERK could be responsible for increases in P70S6K phosphorylation following the retrieval of a remote fear memory. Consistent with this, elevated levels of PTEN result in the inactivation of AKT, which prevents the AKT-
RAS-dependent repression of ERK activation (Rommel et al., 1999; Zimmermann and Moelling, 1999; Mendoza et al., 2011). Collectively, these results suggest that the lack of PTEN repression following the retrieval of a remote memory may allow translational control to be mediated via ERK-MAPK signaling rather than AKT-mTORC1 signaling. This potential pathway will need to be examined in future studies.

Our data suggest that Pten repression is likely regulating reconsolidation through downstream activation of mTORC1 signaling. Despite this, it is possible that PTEN regulates memory reconsolidation through other mechanisms in addition to its control of mTORC1 activation. Notably, through its regulation of AKT, PTEN can have significant control over the activation of ERK-MAPK, a critical regulator of memory storage in neurons (Atkins et al., 1998; Duvarci et al., 2005). Additionally, PTEN has a number of cellular roles independent of the PI3K-AKT pathway and its phosphatase activity (Vivanco et al., 2007; Mounir et al., 2009; Song et al., 2012), suggesting that PTEN could regulate the reconsolidation process through mechanisms both dependent and independent of the PI3K-AKT-mTORC1 pathway. Such diverse roles of PTEN will likely be of interest in future studies examining the role of PTEN in long-term memory formation and storage in neurons. 


\section{A role for repressive histone methylation in memory reconsolidation}

Epigenetic mechanisms have been widely implicated in learningdependent synaptic plasticity (Zovkic et al., 2013; Jarome and Lubin, 2014; Kwapis and Wood, 2014); however, very little is known about how epigenetic mechanisms control transcriptional regulation during the reconsolidation process (Lubin and Sweatt, 2007; Maddox et al., 2014). Furthermore, while histone methylation has been firmly established as a mechanism of memory consolidation (Gupta et al., 2010; Gupta-Agarwal et al., 2012, 2014; Kerimoglu et al., 2013), a role for repressive histone methylation in reconsolidation has yet to be identified. In our present study, we showed for the first time that repressive histone methylation was critical for memory reconsolidation following retrieval. This extends our current knowledge of the epigenetic regulation of memory storage and suggests that repressive histone methylation may be critical for both initial memory formation and modification following retrieval.

Another interesting finding from our study was that PTEN simultaneously had increased levels of H3K27me3 and DNA methylation following retrieval. DNA methylation has been widely implicated in learning-dependent synaptic plasticity (Miller and Sweatt, 2007; Lubin et al., 2008; Feng et al., 2010), and pharmacological inhibition of DNA methylation impairs memory reconsolidation following retrieval (Maddox et al., 2014). However, the genes that are targeted by repressive DNA methylation mechanisms during the reconsolidation process remain elusive. Here, we identify Pten as a target of repressive DNA methylation in the hippocampus following retrieval, suggesting that at least one role of DNA methylation may be repressing protein phosphatase expression during the reconsolidation process. Consistent with this, levels of the protein phosphatase calcineurin determine whether a retrieved memory undergoes reconsolidation or extinction, where greater calcineurin activity favors the latter (Merlo et al., 2014). Thus, repressive histone and DNA methylation may be a critical regulator of whether a memory undergoes reconsolidation or extinction following retrieval. However, it is currently unknown whether other phosphatases, including calcineurin, are targeted by DNA methylation mechanisms in the hippocampus during the reconsolidation process. This will need to be examined further in future studies.

\section{The functional role of $\mathrm{EZH} 2$ in memory reconsolidation}

In the present study, we found that simultaneously reducing Ezh2 and Pten levels rescued deficits in mTOR phosphorylation that normally resulted from a loss of Ezh2 alone, which strongly suggests that retrieval-dependent mTORC1 phosphorylation requires H3K27me3-mediated repression of Pten in the hippocampus. Considering the importance of mTOR signaling in the reconsolidation process, it is interesting to speculate that the recovery of mTOR signaling following Ezh2 knockdown could prevent the memory impairments that normally result from losing Ezh2 alone during retrieval. However, this is unlikely because EZH2 is the functional component of the PCR2, which regulates the expression of hundreds to thousands of genes (Young et al., 2011), many of which could be critical for the reconsolidation process. It is unlikely then that restoring mTOR activation following Ezh2 loss is sufficient to promote normal memory reconsolidation as transcriptional control of numerous other genes is likely to continue to be dysregulated following simultaneous knockdown of Ezh2 and Pten. However, this result does not preclude the importance of identifying epigenetic repression of Pten as a critical regulator of the mTOR activation that is necessary for memory reconsolidation following retrieval, as promoting EZH2 activity or epigenetic repression of Pten may prove to be useful strategies for initiating the modification of memories that normally do not undergo reconsolidation following retrieval (Wang et al., 2009; Sevenster et al., 2013; Alfei et al., 2015; Jarome et al., 2015a). Future research should test whether these "boundary conditions," or circumstances under which reconsolidation does not occur (Nader and Einarsson, 2010; Zhang et al., 2018), can be overcome by enhancing EZH2-mediated transcriptional silencing of Pten following memory retrieval.

It is important to note that while we found that siRNAmediated reductions in Ezh2 before retrieval impaired memory reconsolidation, other interpretations may exist. For example, our siRNA was infused into the dorsal CA1 region $24 \mathrm{~h}$ after training, a time when the initial memory consolidation process is thought to be complete although several cellular mechanisms remain changed, including DNA methylation and some forms of histone methylation (Gupta et al., 2010; Duke et al., 2017). This suggests that Ezh2 knockdown may have interfered with memory maintenance or the lingering consolidation process (Dudai and Eisenberg, 2004; Zovkic et al., 2013). Additionally, while we did not observe memory deficits at the time of retrieval, it is possible that Ezh2 knockdown may have altered some critical cellular mechanisms, resulting in weakening of the memory trace. As a result, it is difficult to infer the selectivity of EZH2 to the reconsolidation process, as it may also be involved in other off-line memory storage processes. Future studies should aim to further test the role of EZH2-mediated H3K27me3 in the memory consolidation, reconsolidation, and maintenance processes using precise, temporally controlled gene manipulation technology.

In conclusion, we found that $\mathrm{H} 3 \mathrm{~K} 27 \mathrm{me} 3$ regulates AKTmTORC1 activation following retrieval via transcriptional repression of Pten. These results provide the first evidence of how mTOR signaling is regulated during learning-dependent synaptic plasticity and suggests that the targeting of H3K27me3 mechanisms might be a useful tool for therapeutic strategies designed using reconsolidation principles meant to attenuate maladaptive memories associated with psychiatric disorders.

\section{References}

Alberini CM (2005) Mechanisms of memory stabilization: are consolidation and reconsolidation similar or distinct processes? Trends Neurosci 28:51-56. CrossRef Medline

Alfei JM, Ferrer Monti RI, Molina VA, Bueno AM, Urcelay GP (2015) Prediction error and trace dominance determine the fate of fear memories after post-training manipulations. Learn Mem 22:385-400. CrossRef Medline

Atkins CM, Selcher JC, Petraitis JJ, Trzaskos JM, Sweatt JD (1998) The MAPK cascade is required for mammalian associative learning. Nat Neurosci 1:602-609. CrossRef Medline

Bredy TW, Barad M (2008) The histone deacetylase inhibitor valproic acid enhances acquisition, extinction, and reconsolidation of conditioned fear. Learn Mem 15:39-45. CrossRef Medline

Brinkman AB, Gu H, Bartels SJ, Zhang Y, Matarese F, Simmer F, Marks H, Bock C, Gnirke A, Meissner A, Stunnenberg HG (2012) Sequential ChIP-bisulfite sequencing enables direct genome-scale investigation of chromatin and DNA methylation cross-talk. Genome Res 22:1128-1138. CrossRef Medline

Day JJ, Sweatt JD (2010) DNA methylation and memory formation. Nat Neurosci 13:1319-1323. CrossRef Medline

Debiec J, LeDoux JE, Nader K (2002) Cellular and systems reconsolidation in the hippocampus. Neuron 36:527-538. CrossRef Medline

Dudai Y, Eisenberg M (2004) Rites of passage of the engram: reconsolidation and the lingering consolidation hypothesis. Neuron 44:93-100. CrossRef Medline

Duke CG, Kennedy AJ, Gavin CF, Day JJ, Sweatt JD (2017) Experience- 
dependent epigenomic reorganization in the hippocampus. Learn Mem 24:278-288. CrossRef Medline

Duvarci S, Nader K, LeDoux JE (2005) Activation of extracellular signalregulated kinase-mitogen-activated protein kinase cascade in the amygdala is required for memory reconsolidation of auditory fear conditioning. Eur J Neurosci 21:283-289. CrossRef Medline

Feng J, Zhou Y, Campbell SL, Le T, Li E, Sweatt JD, Silva AJ, Fan G (2010) Dnmt1 and Dnmt3a maintain DNA methylation and regulate synaptic function in adult forebrain neurons. Nat Neurosci 13:423-430. CrossRef Medline

Frankland PW, Bontempi B, Talton LE, Kaczmarek L, Silva AJ (2004) The involvement of the anterior cingulate cortex in remote contextual fear memory. Science 304:881-883. CrossRef Medline

Gafford GM, Parsons RG, Helmstetter FJ (2011) Consolidation and reconsolidation of contextual fear memory requires mammalian target of rapamycin-dependent translation in the dorsal hippocampus. Neuroscience 182:98-104. CrossRef Medline

Gafford GM, Parsons RG, Helmstetter FJ (2013) Memory accuracy predicts hippocampal mTOR pathway activation following retrieval of contextual fear memory. Hippocampus 23:842-847. CrossRef Medline

Goshen I, Brodsky M, Prakash R, Wallace J, Gradinaru V, Ramakrishnan C, Deisseroth K (2011) Dynamics of retrieval strategies for remote memories. Cell 147:678-689. CrossRef Medline

Gräff J, Joseph NF, Horn ME, Samiei A, Meng J, Seo J, Rei D, Bero AW, Phan TX, Wagner F, Holson E, Xu J, Sun J, Neve RL, Mach RH, Haggarty SJ, Tsai LH (2014) Epigenetic priming of memory updating during reconsolidation to attenuate remote fear memories. Cell 156:261-276. CrossRef Medline

Gupta-Agarwal S, Franklin AV, Deramus T, Wheelock M, Davis RL, McMahon LL, Lubin FD (2012) G9a/GLP histone lysine dimethyltransferase complex activity in the hippocampus and the entorhinal cortex is required for gene activation and silencing during memory consolidation. J Neurosci 32:5440-5453. CrossRef Medline

Gupta-Agarwal S, Jarome TJ, Fernandez J, Lubin FD (2014) NMDA receptor- and ERK-dependent histone methylation changes in the lateral amygdala bidirectionally regulate fear memory formation. Learn Mem 21:351-362. CrossRef Medline

Gupta S, Kim SY, Artis S, Molfese DL, Schumacher A, Sweatt JD, Paylor RE, Lubin FD (2010) Histone methylation regulates memory formation. J Neurosci 30:3589-3599. CrossRef Medline

Halder R, Hennion M, Vidal RO, Shomroni O, Rahman RU, Rajput A, Centeno TP, van Bebber F, Capece V, Garcia Vizcaino JC, Schuetz AL, Burkhardt S, Benito E, Navarro Sala M, Javan SB, Haass C, Schmid B, Fischer A, Bonn S (2016) DNA methylation changes in plasticity genes accompany the formation and maintenance of memory. Nat Neurosci 19:102-110. CrossRef Medline

Herbert TP, Kilhams GR, Batty IH, Proud CG (2000) Distinct signalling pathways mediate insulin and phorbol ester-stimulated eukaryotic initiation factor $4 \mathrm{~F}$ assembly and protein synthesis in HEK 293 cells. J Biol Chem 275:11249-11256. CrossRef Medline

Hoeffer CA, Klann E (2010) mTOR signaling: at the crossroads of plasticity, memory and disease. Trends Neurosci 33:67-75. CrossRef Medline

Jarome TJ, Lubin FD (2014) Epigenetic mechanisms of memory formation and reconsolidation. Neurobiol Learn Mem 115:116-127. CrossRef Medline

Jarome TJ, Ferrara NC, Kwapis JL, Helmstetter FJ (2015a) Contextual information drives the reconsolidation-dependent updating of retrieved fear memories. Neuropsychopharmacology 40:3044-3052. CrossRef Medline

Jarome TJ, Butler AA, Nichols JN, Pacheco NL, Lubin FD (2015b) NF- $\kappa$ B mediates Gadd $45 \beta$ expression and DNA demethylation in the hippocampus during fear memory formation. Front Mol Neurosci 8:54. CrossRef Medline

Jobim PF, Pedroso TR, Christoff RR, Werenicz A, Maurmann N, Reolon GK, Roesler R (2012) Inhibition of mTOR by rapamycin in the amygdala or hippocampus impairs formation and reconsolidation of inhibitory avoidance memory. Neurobiol Learn Mem 97:105-112. CrossRef Medline

Kerimoglu C, Agis-Balboa RC, Kranz A, Stilling R, Bahari-Javan S, BenitoGaragorri E, Halder R, Burkhardt S, Stewart AF, Fischer A (2013) Histone-methyltransferase MLL2 (KMT2B) is required for memory formation in mice. J Neurosci 33:3452-3464. CrossRef Medline
Kreis P, Leondaritis G, Lieberam I, Eickholt BJ (2014) Subcellular targeting and dynamic regulation of PTEN: implications for neuronal cells and neurological disorders. Front Mol Neurosci 7:23. CrossRef Medline

Kwapis JL, Wood MA (2014) Epigenetic mechanisms in fear conditioning: implications for treating post-traumatic stress disorder. Trends Neurosci 37:706-720. CrossRef Medline

Kwapis JL, Jarome TJ, Ferrara NC, Helmstetter FJ (2017) Updating procedures can reorganize the neural circuit supporting a fear memory. Neuropsychopharmacology 42:1688-1697. CrossRef Medline

Lattal KM, Abel T (2004) Behavioral impairments caused by injections of the protein synthesis inhibitor anisomycin after contextual retrieval reverse with time. Proc Natl Acad Sci U S A 101:4667-4672. CrossRef Medline

Lee JL, Everitt BJ, Thomas KL (2004) Independent cellular processes for hippocampal memory consolidation and reconsolidation. Science 304: 839-843. CrossRef Medline

Lee SH, Choi JH, Lee N, Lee HR, Kim JI, Yu NK, Choi SL, Kim H, Kaang BK (2008) Synaptic protein degradation underlies destabilization of retrieved fear memory. Science 319:1253-1256. CrossRef Medline

Lindroth AM, Park YJ, McLean CM, Dokshin GA, Persson JM, Herman H, Pasini D, Miró X, Donohoe ME, Lee JT, Helin K, Soloway PD (2008) Antagonism between DNA and H3K27 methylation at the imprinted Rasgrf1 locus. PLoS Genet 4:e1000145. CrossRef Medline

Liu Y, Wang Y, Zhu G, Sun J, Bi X, Baudry M (2016) A calpain-2 selective inhibitor enhances learning and memory by prolonging ERK activation. Neuropharmacology 105:471-477. CrossRef Medline

Lubin FD, Sweatt JD (2007) The IkappaB kinase regulates chromatin structure during reconsolidation of conditioned fear memories. Neuron 55 : 942-957. CrossRef Medline

Lubin FD, Roth TL, Sweatt JD (2008) Epigenetic regulation of BDNF gene transcription in the consolidation of fear memory. J Neurosci 28:1057610586. CrossRef Medline

Lugo JN, Smith GD, Morrison JB, White J (2013) Deletion of PTEN produces deficits in conditioned fear and increases fragile $\mathrm{X}$ mental retardation protein. Learn Mem 20:670-673. CrossRef Medline

Mac Callum PE, Hebert M, Adamec RE, Blundell J (2014) Systemic inhibition of mTOR kinase via rapamycin disrupts consolidation and reconsolidation of auditory fear memory. Neurobiol Learn Mem 112:176-185. CrossRef Medline

Maddox SA, Schafe GE (2011) Epigenetic alterations in the lateral amygdala are required for reconsolidation of a pavlovian fear memory. Learn Mem 18:579-593. CrossRef Medline

Maddox SA, Watts CS, Schafe GE (2014) DNA methyltransferase activity is required for memory-related neural plasticity in the lateral amygdala. Neurobiol Learn Mem 107:93-100. CrossRef Medline

Maity S, Jarome TJ, Blair J, Lubin FD, Nguyen PV (2016) Noradrenaline goes nuclear: epigenetic modifications during long-lasting synaptic potentiation triggered by activation of beta-adrenergic receptors. J Physiol 594:863-881. CrossRef Medline

McGaugh JL (2000) Memory-a century of consolidation. Science 287: 248-251. CrossRef Medline

Mendoza MC, Er EE, Blenis J (2011) The ras-ERK and PI3K-mTOR pathways: cross-talk and compensation. Trends Biochem Sci 36:320-328. CrossRef Medline

Merlo E, Milton AL, Goozée ZY, Theobald DE, Everitt BJ (2014) Reconsolidation and extinction are dissociable and mutually exclusive processes: behavioral and molecular evidence. J Neurosci 34:2422-2431. CrossRef Medline

Milekic MH, Alberini CM (2002) Temporally graded requirement for protein synthesis following memory reactivation. Neuron 36:521-525. CrossRef Medline

Milekic MH, Pollonini G, Alberini CM (2007) Temporal requirement of $\mathrm{C} / \mathrm{EBPb}$ ta in the amygdala following reactivation but not acquisition of inhibitory avoidance. Learn Mem 14:504-511. CrossRef Medline

Miller CA, Sweatt JD (2007) Covalent modification of DNA regulates memory formation. Neuron 53:857-869. CrossRef Medline

Miller CA, Gavin CF, White JA, Parrish RR, Honasoge A, Yancey CR, Rivera IM, Rubio MD, Rumbaugh G, Sweatt JD (2010) Cortical DNA methylation maintains remote memory. Nat Neurosci 13:664-666. CrossRef Medline

Monfils MH, Cowansage KK, Klann E, LeDoux JE (2009) Extinction- 
reconsolidation boundaries: key to persistent attenuation of fear memories. Science 324:951-955. CrossRef Medline

Mounir Z, Krishnamoorthy JL, Robertson GP, Scheuner D, Kaufman RJ, Georgescu MM, Koromilas AE (2009) Tumor suppression by PTEN requires the activation of the PKR-eIF2alpha phosphorylation pathway. Sci Signal 2:ra85. CrossRef Medline

Mucic G, Sase S, Stork O, Lubec G, Li L (2015) Networks of protein kinases and phosphatases in the individual phases of contextual fear conditioning in the C57BL/6J mouse. Behav Brain Res 280:45-50. CrossRef Medline

Nader K, Einarsson EO (2010) Memory reconsolidation: an update. Ann N Y Acad Sci 1191:27-41. CrossRef Medline

Nader K, Schafe GE, Le Doux JE (2000) Fear memories require protein synthesis in the amygdala for reconsolidation after retrieval. Nature 406: 722-726. CrossRef Medline

Parsons RG, Gafford GM, Helmstetter FJ (2006) Translational control via the mammalian target of rapamycin pathway is critical for the formation and stability of long-term fear memory in amygdala neurons. J Neurosci 26:12977-12983. CrossRef Medline

Reddington JP, Perricone SM, Nestor CE, Reichmann J, Youngson NA, Suzuki M, Reinhardt D, Dunican DS, Prendergast JG, Mjoseng H, Ramsahoye BH, Whitelaw E, Greally JM, Adams IR, Bickmore WA, Meehan RR (2013) Redistribution of H3K27me3 upon DNA hypomethylation results in de-repression of polycomb target genes. Genome Biol 14:R25. CrossRef Medline

Rommel C, Clarke BA, Zimmermann S, Nuñez L, Rossman R, Reid K, Moelling K, Yancopoulos GD, Glass DJ (1999) Differentiation stagespecific inhibition of the raf-MEK-ERK pathway by akt. Science 286 : 1738-1741. CrossRef Medline

Schafe GE, LeDoux JE (2000) Memory consolidation of auditory pavlovian fear conditioning requires protein synthesis and protein kinase $\mathrm{A}$ in the amygdala. J Neurosci 20:RC96. CrossRef Medline

Sevenster D, Beckers T, Kindt M (2013) Prediction error governs pharmacologically induced amnesia for learned fear. Science 339:830-833. CrossRef Medline

Song MS, Salmena L, Pandolfi PP (2012) The functions and regulation of the PTEN tumour suppressor. Nat Rev Mol Cell Biol 13:283-296. CrossRef Medline

Sperow M, Berry RB, Bayazitov IT, Zhu G, Baker SJ, Zakharenko SS (2012) Phosphatase and tensin homologue (PTEN) regulates synaptic plasticity independently of its effect on neuronal morphology and migration. J Physiol 590:777-792. CrossRef Medline

Statham AL, Robinson MD, Song JZ, Coolen MW, Stirzaker C, Clark SJ (2012) Bisulfite sequencing of chromatin immunoprecipitated DNA
(BisChIP-seq) directly informs methylation status of histone-modified DNA. Genome Res 22:1120-1127. CrossRef Medline

Steelman LS, Chappell WH, Abrams SL, Kempf RC, Long J, Laidler P, Mijatovic S, Maksimovic-Ivanic D, Stivala F, Mazzarino MC, Donia M, Fagone P, Malaponte G, Nicoletti F, Libra M, Milella M, Tafuri A, Bonati A, Bäsecke J, Cocco L, et al (2011) Roles of the Raf/MEK/ERK and PI3K/ PTEN/Akt/mTOR pathways in controlling growth and sensitivity to therapy-implications for cancer and aging. Aging (Albany NY) 3:192222. CrossRef Medline

Taubenfeld SM, Milekic MH, Monti B, Alberini CM (2001) The consolidation of new but not reactivated memory requires hippocampal C/EBPbeta. Nat Neurosci 4:813-818. CrossRef Medline

Vivanco I, Palaskas N, Tran C, Finn SP, Getz G, Kennedy NJ, Jiao J, Rose J, Xie W, Loda M, Golub T, Mellinghoff IK, Davis RJ, Wu H, Sawyers CL (2007) Identification of the JNK signaling pathway as a functional target of the tumor suppressor PTEN. Cancer Cell 11:555-569. CrossRef Medline

Wang SH, de Oliveira Alvares L, Nader K (2009) Cellular and systems mechanisms of memory strength as a constraint on auditory fear reconsolidation. Nat Neurosci 12:905-912. CrossRef Medline

Webb WM, Sanchez RG, Perez G, Butler AA, Hauser RM, Rich MC, O'Bierne AL, Jarome TJ, Lubin FD (2017) Dynamic association of epigenetic H3K4me3 and DNA 5hmC marks in the dorsal hippocampus and anterior cingulate cortex following reactivation of a fear memory. Neurobiol Learn Mem 142:66-78. CrossRef Medline

Winocur G, Moscovitch M (2011) Memory transformation and systems consolidation. J Int Neuropsychol Soc 17:766-780. CrossRef Medline

Young MD, Willson TA, Wakefield MJ, Trounson E, Hilton DJ, Blewitt ME, Oshlack A, Majewski IJ (2011) ChIP-seq analysis reveals distinct H3K27me3 profiles that correlate with transcriptional activity. Nucleic Acids Res 39:7415-7427. CrossRef Medline

Zhang JJ, Haubrich J, Bernabo M, Finnie PSB, Nader K (2018) Limits on lability: boundaries of reconsolidation and the relationship to metaplasticity. Neurobiol Learn Mem. Advance online publication. Retrieved Feb 21, 2018. doi: 10.1016/j.nlm.2018.02.018.

Zhang J, Ji F, Liu Y, Lei X, Li H, Ji G, Yuan Z, Jiao J (2014) Ezh2 regulates adult hippocampal neurogenesis and memory. J Neurosci 34:5184-5199. CrossRef Medline

Zimmermann S, Moelling K (1999) Phosphorylation and regulation of raf by akt (protein kinase B). Science 286:1741-1744. CrossRef Medline

Zovkic IB, Guzman-Karlsson MC, Sweatt JD (2013) Epigenetic regulation of memory formation and maintenance. Learn Mem 20:61-74. CrossRef Medline 